\title{
Deleveraging and Mortgage Curtailment
}

\author{
Meagan N. McCollum ${ }^{\mathrm{a}, *}$, Hong Lee ${ }^{\mathrm{b}}$, R. Kelley Pace ${ }^{\mathrm{c}}$ \\ ${ }^{a}$ Baruch College, the City University of New York, Zicklin School of Business, Department of Real Estate \\ New York, New York 10010 \\ ${ }^{b}$ Wright State University, Raj Soi College of Business, Department of Finance \& Financial Services \\ Dayton, Ohio 45435 \\ ${ }^{c}$ Louisiana State University, E.J. Ourso College of Business, Department of Finance \\ Baton Rouge, Louisiana, 70803
}

\begin{abstract}
Using monthly loan-level data, individual partial prepayments (curtailments) from January 2001 to June 2011 are observed for mortgages in twenty metropolitan statistical areas. Contrary to some earlier assertions, American homeowners now frequently commit funds towards their mortgage payments in excess of the amount due; over $30 \%$ of loans outstanding have made at least one curtailment payment. After controlling for borrower and loan-level variables, we show that the latent propensity to curtail has steadily risen from 2003 to 2006 and remains at elevated levels. Therefore, curtailment provides an example of consumer deleveraging behavior that began prior to the Great Recession.
\end{abstract}

Keywords: mortgages, curtailment, prepayment, deleveraging, personal finance JEL classification: D14, E32, G01, G21

\section{Introduction}

Consumer debt levels fell during the Great Recession. Various reasons have been posited for this change, including increased lending standards and a reduction in the demand for debt. During the crisis, households responded to adverse economic conditions by increasing savings. One of the ways that households engaged in savings behaviors was through the reduction of outstanding consumer debt, including paying down mortgage debt (Charkrabarti et al. 2011).

Advantages of examining changes in existing mortgage loans include: (1) Unlike new debt, existing debt is not directly affected by changing lending standards ${ }^{1}$; (2) Aggregation bias is avoided because detailed observations are available on individual behavior; (3) Deleveraging due to charge-offs or foreclosures can be separated from deleveraging due to acceleration of debt repayments.

The institutional setting of mortgage payments provides a relatively controlled setting to examine borrowers' leverage choices and motivations for reducing debt. Initially, it must be determined if borrowers are rate sensitive in their deleveraging decisions. If so, partially prepaying a mortgage (curtailment) is primarily an investment strategy wherein individuals choose to minimize (maximize) their leverage when rates are high

\footnotetext{
* Corresponding author

Email addresses: meagan.mccollum@baruch.cuny.edu (Meagan N. McCollum), hong.lee@wright.edu (Hong Lee), kpace@lsu.edu (R. Kelley Pace)

${ }^{1}$ Although there is no direct effect, individuals could still modify their future borrowing behavior due to changes in opportunities.
} 
(low) by making excess (only minimum scheduled) principal payments. If individuals are not rate sensitive, this suggests that other factors may drive curtailment behavior. In general, household attitudes towards debt (and by extension, the desire to reduce household debt levels) are also related to non-pecuniary social psychological factors in consumer debt and savings behaviors (Lunt and Livingstone 1991, Lea et al. 1993, 1995, Brown et al. 2005).

Much of the deleveraging literature examines household behavior in response to the Great Recession, which is associated with subsequently lower levels of leverage (Bricker et al. 2011). In fact, aggregate consumer debt did not begin to decline until mid-2008 (Brown et al. 2011). In contrast to these results, we find that the latent propensity to engage in curtailment payments (after controlling for many economic factors) began to increase as early as 2003 during a time period (2002-2007) where, in aggregate, consumers demanded higher levels of debt (Weller 2007). This is important because it shows that within the controlled setting of curtailment, household deleveraging (all else equal) began prior to the Great Recession.

Curtailment payments are applied directly to the mortgage principal balance. A borrower who elects to make a partial prepayment reduces his outstanding debt, the life of the mortgage, and future interest costs. Making a curtailment payment is a voluntary action on the part of the borrower and may be done at any point in time ${ }^{2}$ and in any amount less than the total balance outstanding. ${ }^{3}$

Mortgage curtailment has historically been a relatively rare choice for American homeowners, but we observe a dramatic increase in the popularity of this behavior in recent years (see Figure 1). In January 2004, only $0.23 \%$ of borrowers chose to make a curtailment payment of at least $\$ 100$ that month; the same time in $20051.41 \%$ chose curtailment. In January 2006, 6.63\% of borrowers chose to curtail their mortgages that month. Additionally, the monthly curtailment rate remains high through June 2011, the end of our sample period.

Note that there is a dramatic jump between 4Q 2005 and 1Q 2006, but after accounting for borrower and loan-level variables the latent propensity to engage in curtailment as a payment choice begins three years earlier and shows a more gradual rise over the sample period. Specifically, after modeling a borrower's payment choice in a given month (late, current, curtailment, or full prepayment) and controlling for a host of characteristics related to mortgage payment choices, the gray line (right axis) in Figure 1 is a plot of the yearly fixed effects for the curtailment outcome category. ${ }^{4}$ Curtailment behavior continues to rise in popularity through the end of our sample period, June 2011.

\footnotetext{
${ }^{2}$ Theoretically, curtailments can even be made even when the mortgage is delinquent, but in this case any excess payment will first be applied to past balance due and late fees before being considered a curtailment.

${ }^{3}$ Many mortgages have a prepayment penalty in effect for the first 12-60 months of the life of the loan that prevents a borrower from repaying greater than $20 \%$ of the mortgage outstanding in excess of the regular payment schedule in a single year without facing a substantial penalty.

${ }^{4}$ In the regression model, the omitted year is 2011.
} 
$10 \%$

$8 \%$

$6 \%$
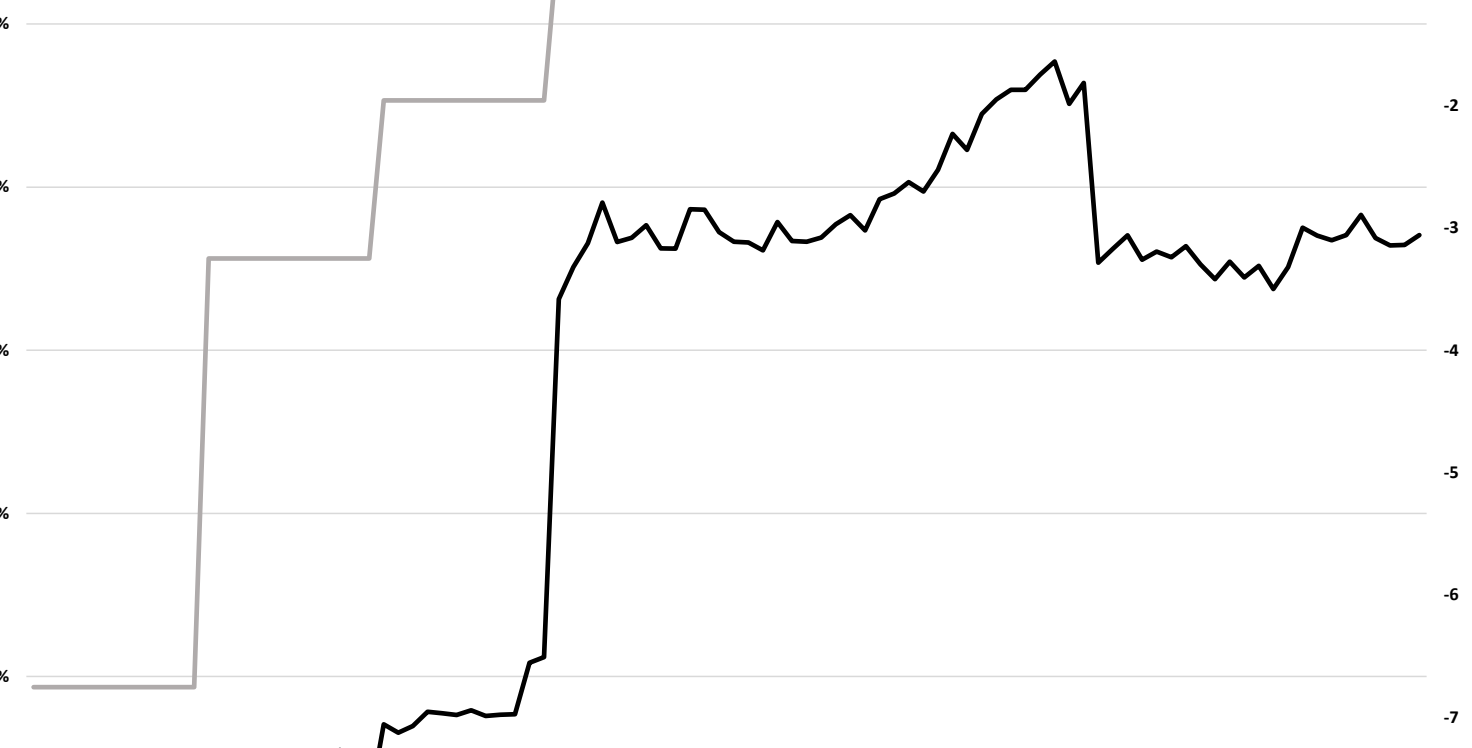

$0 \%$

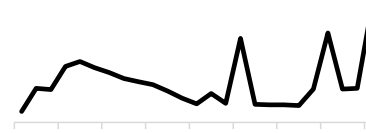

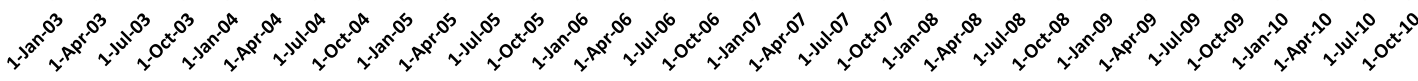

The curtailment rate is calculated using data from the private securitized mortgage market. This graph uses the $\$ 100$ minimum value of curtailment. The black line (left axis) graphs the raw monthly curtailment rate. The gray line (right axis) graphs the coefficients of the yearly fixed effects (2011 is the omitted year) from our main regression model. 
We cannot observe borrowers' non-mortgage consumer debts. However, mortgage debt represents $70 \%$ of all household liabilities (Justiniano et al. 2013). Often mortgage debt is less expensive than other forms of debt such as credit card debt or personal loans; in this case rational deleveraging should appear in those higher cost debts prior to reduction of mortgage debt. If mortgage debt is relatively expensive, it would be difficult for borrowers to replace large amounts of mortgage debt with other forms of consumer debt. Nonetheless, not having information on individual borrowers' non-mortgage debts presents a possible omitted variable issue.

Mortgage curtailment is often omitted from mortgage pricing and payment models, but we suggest that this event reveals additional information about and insights into borrower behavior. We show as the spread between current mortgage interest rate and the short term risk-free rate increases, the probability of making a curtailment payment increases, particularly for borrowers estimated to have positive equity in the property at the time of observation. A certain subset of homeowners who have (unobservable) discretionary income available and do not currently value the default option on their mortgage ${ }^{5}$ may be motivated to commit those funds to accelerate paying down their relatively high interest rate mortgage as return on safe investments, such as savings accounts, becomes less unattractive.

The goal of this paper is to better understand the motivations for mortgage curtailment behavior, and by extension household deleveraging behavior, among US homeowners. After allowing for variation in loan, borrower, locational, vintage, and servicer characteristics, we show that the choice to make additional payments has become more attractive to borrowers in recent years. This documents the increasing importance of mortgage curtailment in the US mortgage market.

The rest of the paper is organized as follows: Section 2 briefly outlines previous curtailment literature, discusses borrower behavior, and presents the choice to curtail in an options framework, Section 3 discusses the empirical models employed,

Section 4 discusses the data used in this study, defines key variables, and provides summary statistics, Section 5 presents the results,

and Section 6 summarizes as well as proposes directions for future research.

\section{Literature Review and Discussion}

First, we summarize the previous research related to mortgage curtailment in Section 2.1. Next, we discuss some interesting patterns of curtailment behavior and present several potential economic and behavioral motivations for engaging in curtailment behavior in Section 2.2. Finally, we discuss the choice to curtail within an options framework in Section 2.3 .

\subsection{Previous Research}

Mortgage curtailment has not received much attention in the real estate literature. Relative to the extensive academic literature on prepayments in full, the literature on curtailment is limited. Also, a large portion of research related to mortgage payment decisions is targeted towards the importance of payment events for

\footnotetext{
${ }^{5}$ That is, they view the timely repayment of their outstanding mortgage debt as certain.
} 
the pricing of mortgage backed securities. Campbell (2006) notes that despite the importance of housing and mortgage debt for households, there is a limited amount of research on mortgage decisions from the perspective of individual households. By exploring determinants of mortgage curtailment decisions for individual borrowers, we contribute to the literature on personal mortgage payment choices.

The first study to investigate mortgage curtailment is Hayre and Lauterbach (1991). They highlight the importance of accounting for partial prepayments in calculating the weighted average maturities (WAM) of mortgage pools; failing to account for curtailment will upwardly bias the average age of the mortgage pool. Budinger and Fan (1995) examine curtailments in the context of pools of jumbo loans. They find that curtailments seldom occur early in the life of the mortgage and that curtailment rates significantly increase in the later years of a mortgage. Budinger and Fan also observe a trend of seasonality with curtailment at the pool level being least likely in the fall months and increasing curtailment frequency beginning in December until reaching a peak in April.

A borrower who makes a curtailment payment may choose to repeat this behavior several times over the course of the life of the loan; $\mathrm{Fu}$ (1997) finds that records of previous curtailment for a given mortgage greatly enhance the chances that loan will make a curtailment in the future. Although they do not specifically study curtailment, Amromin, Huang, and Sialm (2007) document the reluctance of households to participate in financial markets and how paying down existing debt can be viewed as an alternate method of personal savings.

Budinger and Fan (1995) identify three variables: the mortgage interest rate, loan size, and loan to value (LTV) ratio, that help forecast future curtailments. A borrower's liquidity, value of retiring debt, loan age, and available alternative uses of discretionary funds help predict the likelihood of engaging in curtailment behavior (Abrahams 1997).

Additionally, some previous studies have focused largely on the impact of curtailments in Asian markets since curtailment behavior has been linked to populations with high household savings rates (Lin et al. 2005). In another study of curtailment behavior in Asian markets, Ling and Yang (2005) find individuals who curtail their mortgages exhibit different behaviors than those who do not; curtailment is associated with a $85 \%$ reduction in default risk and a $23 \%$ increase in the probability of future prepayment. These behaviors have implications for both the pricing of and investment in mortgage backed securities. In the most recent study of this behavior by American homeowners using survey data to infer curtailment behavior, a household's propensity to save is found to be highly positively correlated with the probability of mortgage curtailment (as measured by being ahead on mortgage payments) and that liquidity risk also factors into the decision to make a curtailment payment (Adleman, Cross, and Shrider 2010). In contrast, ours is the first study to specifically examine loan-level time-varying curtailment behavior in the American mortgage market.

\subsection{Curtailment Motivation and Descriptive Statistics}

Curtailment is an individual expression of a borrower's desired level of mortgage. Conditional on borrowers having funds available to make a curtailment payment, the choice to do so or not will be a reflection of their preferences among available alternatives. ${ }^{6}$ A household that engages in this behavior has the choice to

\footnotetext{
${ }^{6}$ Mortgage curtailment is always the choice of a borrower, not an obligation. Since a borrower is never obligated to curtail their mortgage, the amount of money observed to be used as a curtailment payment is some unknown portion of a given borrower's unobservable discretionary income.
} 
spend discretionary income in any manner they see fit, but has elected to apply funds towards the principal outstanding on their mortgage. Household investment and leverage preferences vary across time and may be impacted by changes in variables that are closely connected to housing and mortgage decisions such as interest rate levels and changes in housing price levels. A borrower who desires to decrease their overall financial leverage may have other outstanding debts that may have higher interest rates (such as credit card debt) or shorter amortization periods (such as automobile loans or student loans) that we do not observe in our dataset. Rationally, a borrower may choose to prioritize to accelerate repayment of these forms of debt instead of reducing mortgage debt, therefore the study of mortgage curtailment cannot provide an exhaustive analysis of a borrower's deleveraging actions, but it can characterize the borrower's appetite for reducing debt in for what a majority of households is their largest financial liability, their home mortgage.

Additionally, a curtailment payment is a reaffirmation of the borrower's commitment to repay the mortgage debt. By putting more funds towards the loan than the mortgage contract requires, the borrower who engages in mortgage curtailment reveals they place a low value on the option to default. Observing curtailment behavior gives insight into borrower choices beyond what is revealed by prepayment or default decisions, such as appetite for leverage. When a borrower prepays or defaults they are no longer observable, but when a borrower makes a curtailment payment we can continue to monitor their behavior. When the curtailment option is optimally exercised by a rational household, the full menu of mortgage options is available in the next payment period ranging from default to prepayment, but if a borrower prepays in full or loses the home in foreclosure, the mortgage is terminated and no mortgage options may be exercised in the future. Curtailment payments are part of an intertemporal household maximization decision; rational borrowers engaging in this behavior must be of the belief that curtailment payments provide the most utility for a given amount of discretionary income at a given point in time (Chinloy 1993). Therefore, curtailment decisions hinges on both the desire and ability to make curtailment payments.

For many borrowers, mortgage curtailment appears to be a regular planned behavior. ${ }^{7}$ Looking at the dollar amount of curtailment payments, for all observations with curtailment payment of at least $\$ 100,25.69 \%$ make a curtailment payment of exactly $\$ 100,14.04 \%$ curtail $\$ 200,10.69 \%$ curtail $\$ 500$, and $9.34 \%$ curtail $\$ 1,000$. Additionally, $36.24 \%$ (1,692,475 monthly remittance reports) of all observations with curtailment observations are in the amount of $\$ 500$ or more and $18.97 \%$ of borrowers that engage in this behavior $(890,359$ monthly remittance reports) curtail $\$ 1,000$ or more. $^{8}$ A portion of the distribution of all curtailments for all monthly observations is presented in Figure 2. Although not presented graphically, the curtailments over $\$ 1,000$ also have clear spikes in the distribution at $\$ 1,000$ intervals; $2.99 \%$ of all remittance reports containing a curtailment are in the amount of exactly $\$ 2,000,1.15 \%$ are exactly $\$ 3,000,0.56 \%$ are $\$ 4,000$, and $1.24 \%$ of remittance reports have curtailments of exactly $\$ 5,000$.

Considering all loans active as of June 2011, 30.26\% had at least one observation of a curtailment at least $\$ 100$ in their payment history and $11.38 \%$ had at least one record of a curtailment of $\$ 1,000$ or more. Of all borrowers making curtailments over our sample period, approximately $65 \%$ made two or more curtailment payments in our observation period (Figure 3). This contrasts with the earlier findings of Adleman, Cross, and Shrider (2010), who observed that among borrowers in the 1992, 1995, 1998, 2001, and 2004 iterations of the Federal Reserve's Survey of Consumer Finances, $22.20 \%$ of borrowers made an curtailment payment of

\footnotetext{
${ }^{7}$ A complete description of the curtailment criteria and measurement is presented in Section 4.2.

${ }^{8}$ Curtailments over $\$ 10,000$ were not considered in calculating these distributions.
} 
any amount sometime in the life their mortgage. Note that we are only including loans that were originated in 1998 or later and our observation period ends in mid-2011, we have very few observations loans over 10 years old in our sample ${ }^{9}$ and as noted by Budinger and Fan (1995) and Abrahams (1997) higher levels of curtailment are associated with older loans, particularly loans nearing the end of their amortization schedule. What we are primarily observing is curtailments of loans relatively early in their amortization schedules.

As additional evidence that curtailment is an economically significant behavior, we compare average curtailment amounts (using $\$ 100$ as a minimum value an individual observation being recorded as curtailment) to average principal and total payment due across all observations in our sample. On average across the sample period for every dollar of principal due, there are an additional 12 cents paid as curtailment and on average for every dollar of total payment (principal plus interest) due, we observe an additional 8 cents paid as curtailment.

Figure 2: Curtailments by Dollar Amount

Curtailments under $\$ 100$ or greater than $90 \%$ of loan balance outstanding are counted as 0

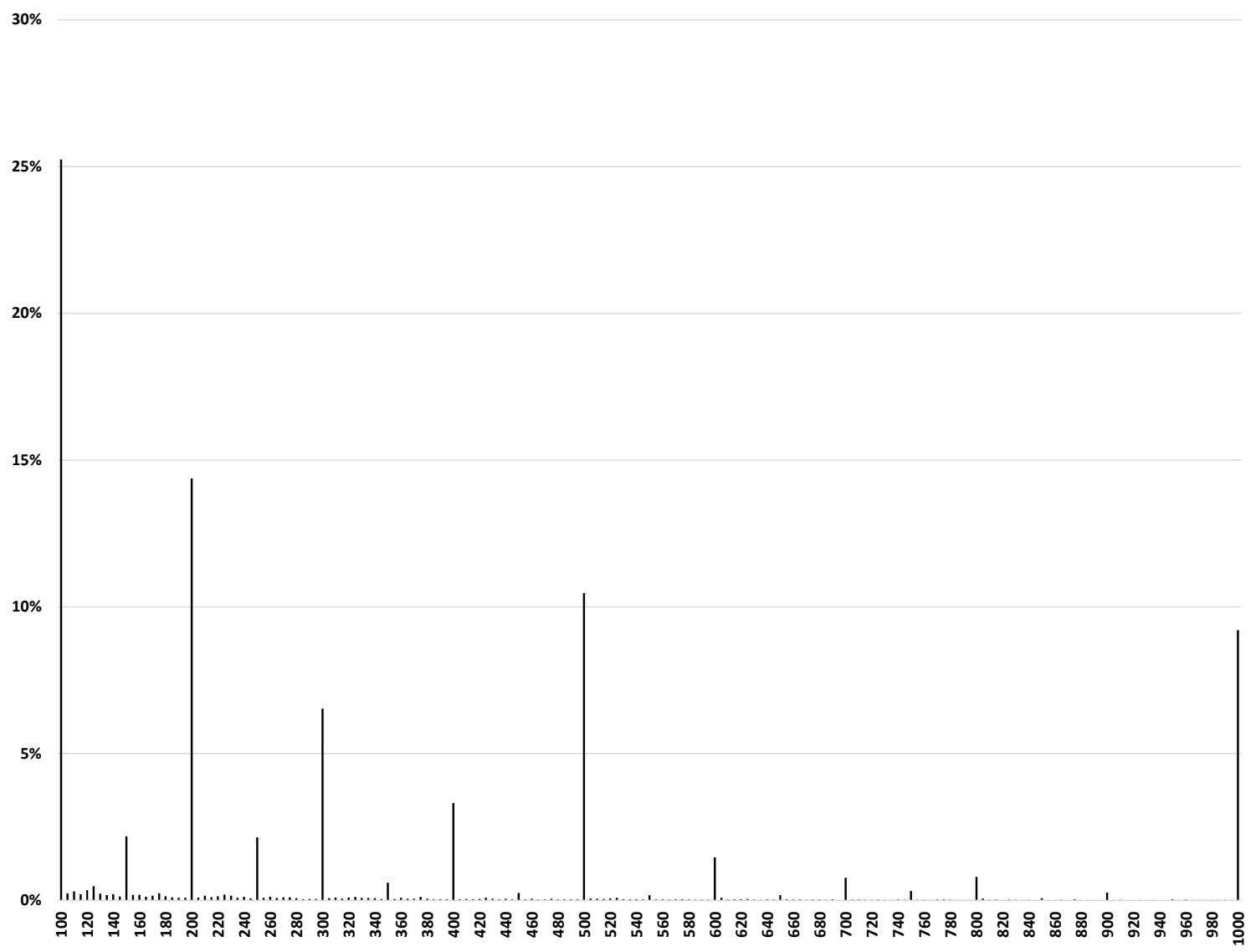

\footnotetext{
${ }^{9}$ The average age of a loan in our sample is 32 months and approximately $95 \%$ of the sample was originated post-2002.
} 
Figure 3: Number of Curtailments Per Loan

Only loans containing at least one curtailment are graphed. $14.75 \%$ of curtailing borrowers had more than 20 curtailment observations.

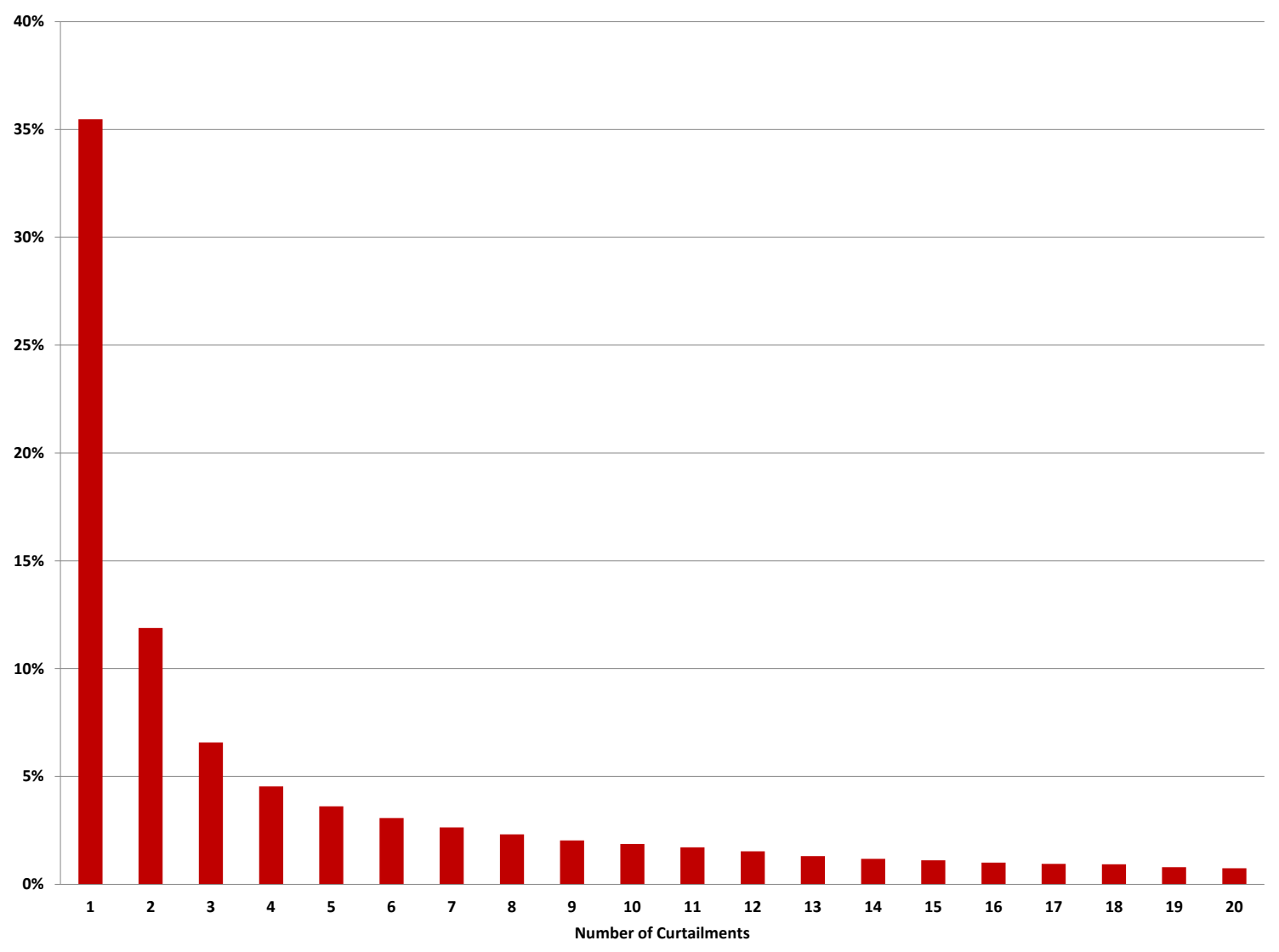

\subsection{Option aspects of curtailment}

Options pricing provides a canonical way to model mortgage choices (Kau and Keenan 1995, Kau et al. 1992, 1995 and Quigley and Van Order 1995). Another way to characterize the choice to curtail a mortgage is within an option pricing framework in which the decision to make an extra payment is a non-terminal choice (Chinloy 1993). However, due to a lack of popularity of curtailment as a payment option to American borrowers in the past, previous empirical studies using US data omit the curtailment choice from the menu of options considered by the borrower (Fei 2010).

A borrower must make a decision each period of whether to pay, not pay, prepay in full, or to partially prepay (curtail). In a myopic world, where $P$ is the property price, $B$ is the mortgage balance, $r$ is the current rate of interest, and $c$ is the existing rate on the mortgage contract, the borrower would pay in the state of the world where $P>B$ and $c<r$, would refinance (prepay) in the state of the world where $P>B$ and $c>r$, and would not pay in the state of the world where $P<B$. Note, curtailment does not emerge in such a myopic world. However, in the option pricing view of mortgages where the borrower makes decisions today 
based on various states of the world over the future, all possible states have some potential influence on decisions made today. For example, borrowers could decide to pay today even if $P<B$ because of possible states of the world such that $P_{t}>B_{t}$, where $t$ is a future time period.

Are there any states of the world or situations where curtailment has pecuniary value? Consider the situation where the borrower needs to have sufficient equity to fall below a maximum loan-to-value ratio $\left(L T V_{\max }\right)$ to refinance. ${ }^{10}$ Now suppose the borrower does not meet the loan-to-value restriction and also pays an above market rate $\left(c>r\right.$ and $\left.P<B / L T V_{\max }\right)$. Furthermore, suppose the borrower does not anticipate or intend to default, and wishes to refinance. In this case, to refinance the borrower must reduce the balance $B$ (assuming constant $P$ ).

There are two ways to do this. The first way would be to invest money at prevailing short-term risk-free interest rates $s$ until acquiring enough funds to reduce $B$ sufficiently. The second way would be to partially prepay $B$ over time until $B$ has reached the desired level. Consider environments where $r<c$ and with positive sloping yield curves, $s<r<c$. In this case, curtailment will have a pecuniary advantage over investing funds and deferred prepayment (with the important proviso that the borrower does not anticipate or intend to default). Since curtailment has value in some states of the world, it has a non-zero probability of occurrence. Given that the probabilities associated with the various choices (default, current, curtailment, and prepayment) sum to one, the introduction of the curtailment choice affects the probability of the other choices. ${ }^{11}$ To assess the factors that influence the curtailment choice, the curtailment option must be considered alongside the options to default, make the contractually obligated payment, or fully prepay the loan.

\section{Empirical Strategy}

The simplest way of estimating multiple probabilities is by multinomial logistic regression which has been employed in several other mortgage studies (Archer et al 1996, Clapp et al 2001, Clapp et al 2006). ${ }^{12}$ Multinomial logit estimates a separate equation for each identified choice as shown in (1) where $l$ is the identified choice which runs from 1 to $J$ as shown in (2), $i$ is the $i$ th individual observation, $x_{i t}$ is a 1 by $k$ vector containing the $i$ th individual's explanatory variable data in the $t$ th time period, and $y_{i t}$ is the $i$ th individual's choice in the $t$ th time period. However, the mortgage data contains information about individuals without differentiating information specific to each choice. Accordingly, one choice is not identified and becomes the base case. The other estimated equations are in terms of the differences between the respective choice and the base case. Let $\gamma^{(l)}$ represent the difference between the $k$ by 1 parameter vector associated with the $l$ th choice $\beta^{(l)}$ and the base case choice parameter values $\beta^{(0)}$.

\footnotetext{
${ }^{10}$ Daglish (2009) discusses the potentially diminished value of the default option for subprime borrowers within a declining interest rate environment.

${ }^{11}$ Moreover, curtailment in a given period could be followed by states of the world in which continuing curtailment, reverting to regular payment, or choosing a full prepayment could be optimal. In this sense, curtailment can be viewed in a compound options context.

${ }^{12}$ Multinomial logit was chosen over multinomial probit because of computational difficulties and chosen over a competing hazards model due to the potentially repetitive nature of the curtailment choice, unlike the terminal choices of default or prepayment.
} 


$$
\begin{aligned}
\operatorname{Pr}\left(y_{i t}=l\right) & =\frac{\exp \left(x_{i t} \gamma^{(l)}\right)}{1+\sum_{j=1}^{J} \exp \left(x_{i t} \gamma^{(j)}\right)} \\
\gamma^{(l)} & =\beta^{(l)}-\beta^{(0)}, l=1, \cdots, J
\end{aligned}
$$

In this context, the base case is that the mortgage is current; the other cases are late, curtailment, or fully prepaid.

Additionally, we employ a two-limit tobit regression model to investigate the effects of the variables of interest on the amount of curtailment a mortgagee, $i$, chooses to make in a given time period, $t$.

We estimate a model where $g_{i t}^{*}$ is the unobserved latent variable of interest, the amount of curtailment a borrower makes of the form:

$$
g_{i t}^{*}=x_{i t} \beta+\varepsilon_{i t}
$$

where $x_{i t}$ is a vector of borrower characteristics. These may include fixed effects for loan vintage, location, observation year and time, and servicer that are identified at the individual loan level. The observed curtailment amount, $g_{i t}$, is related to the latent variable $g_{i t}^{*}$ as follows ${ }^{13}$ :

$$
g_{i t}= \begin{cases}\$ 0 & \text { if } g_{i t}^{*} \leq \$ 0 \\ g_{i t}^{*} & \text { if } \$ 0<g_{i t}^{*}<\$ 13,215 \\ \$ 13,215 & \text { if } g_{i t}^{*} \geq \$ 13,215\end{cases}
$$

\section{Data, Variable Definitions and Summary Statistics}

We describe data sources and detail our sample section procedure in Section 4.1. Next, we define our measurements of curtailment in Section 4.2. We define variables and present hypothesis in Section 4.3. Last, we provide summary statistics and a correlation matrix for key variables in Section 4.4.

\subsection{Data}

Loan-level data comes from Blackbox Logic, LLC (BBx). ${ }^{14}$ BBx covers over $90 \%$ of non-agency residential securitized mortgages including prime, Alt-A, and subprime loans. ${ }^{15}$ The database has detailed mortgage contract information at loan origination and monthly records of mortgage payment information. BBx contains information on 21,409,761 loans, and 708,373,906 remittance records (497,925,228 of which are for single family properties) as of June 2011. For details of the market coverage of the BBx database, see Table $1 .{ }^{16}$

\footnotetext{
${ }^{13}$ The number of left censored observations depends on the threshold for curtailment used in a given model (e.g. $\$ 100$, or $\$ 1,000)$. The right-censoring value, $\$ 13,215$, is the $99 \%$ value for positive curtailment observations.

${ }^{14}$ Detailed BBx data information is available at http://www.bbxlogic.com/data.htm.

${ }^{15}$ Agarwal, Chang and Yavas (2012) find evidence of adverse selection in the prime securitzed market, but no clear evidence of adverse selection in the subprime market using similar large mortgage datasets.

${ }^{16}$ Market coverage was calculated using the methodology from Pafenberg (2005).
} 
Table 1: BBx Market Coverage 2001-2010 (in \$trillion)

\begin{tabular}{rrrrrr}
\hline Year & BBx & Total Securitized & Total Single Family & Securitized Market & Total Market \\
\hline 2001 & $\$ 0.11$ & $\$ 3.54$ & $\$ 5.66$ & $3 \%$ & $2 \%$ \\
2002 & $\$ 0.25$ & $\$ 3.96$ & $\$ 6.41$ & $6 \%$ & $4 \%$ \\
2003 & $\$ 0.34$ & $\$ 7.24$ & $\$ 4.46$ & $8 \%$ & $5 \%$ \\
2004 & $\$ 0.59$ & $\$ 4.97$ & $\$ 8.27$ & $12 \%$ & $7 \%$ \\
2005 & $\$ 1.10$ & $\$ 5.67$ & $\$ 9.39$ & $19 \%$ & $12 \%$ \\
2006 & $\$ 1.77$ & $\$ 6.60$ & $\$ 11.17$ & $27 \%$ & $17 \%$ \\
2007 & $\$ 2.25$ & $\$ 7.40$ & $\$ 11.07$ & $29 \%$ & $20 \%$ \\
2008 & $\$ 2.19$ & $\$ 7.55$ & $\$ 10.87$ & $24 \%$ & $17 \%$ \\
2009 & $\$ 1.84$ & $\$ 7.60$ & $\$ 10.52$ & $50 \%$ & $15 \%$ \\
2010 & $\$ 1.53$ & $\$ 3.05$ & & & \\
\hline
\end{tabular}

Securitized market includes total securitized market, public and private. BBx covers over 90\% of the total private securitized market.

Monthly home price index levels for the twenty major metropolitan areas comes from the S\&P Case-Shiller Composite 20 (CS-20) index. We limit our study to the metropolitan statistical areas represented in the CS-20 index. ${ }^{17}$ The Case-Shiller index methodology provides a list of counties included in each of the CS20 areas; loans in the BBx database are also identified by county as one of the list of variables recorded about the loan at origination. Included in our sample are loans in these geographic areas for which loan characteristics at origination and monthly payment information is available. New observations enter our sample as additional loans are securitized. Mortgages may be seasoned before they appear as observations in our sample since they only enter the database at the point of securitization. ${ }^{18}$ Since the CS-20 index is based on single family residential transactions (1-4 home properties), we exclude large investment properties (such as apartment complexes). Additionally, for simplicity, we exclude junior mortgages and interest-only loans from our sample.

The key information utilized from BBx is the series of monthly payment data for the loans for properties that are located in a county that is included in a CS-20 MSA. From these remittance records, excess principal payments (curtailments) can be identified on the individual level by date and amount. Additional information used from BBx includes loan origination date, securitization date, loan to value (LTV) ratio at origination, FICO score at origination, original loan balance, payment records for each month, prepayment penalty indicator, loan term (15 or 30 year $)^{19}$, loan interest type (adjustable rate or fixed rate mortgage), loan documentation level, and loan interest rate both at origination and observation dates.

Prevailing monthly market mortgage rates are from the Federal Reserve, 12 month London Interbank Offered Rate (LIBOR) based on the U.S. dollar are from the British Bankers' Association, and historical loan

\footnotetext{
${ }^{17}$ Detailed information about Case-Shiller geographic coverage and methodology is available at http://www.standardandpoors.com/indices/sp-case-shiller-home-price-indices/en/us/?indexId=spusa-cashpidff-p-us--
${ }_{18}$ For example, in 2001 there could be observations from a 30 year loan originated as early as 1971 . However, over $99 \%$ of the mortgages in this database are originated in 1998 or later. For simplicity, we exclude loans originated before 1998 from our sample.

${ }^{19}$ Loans of other maturities, such as 20 year or 40 year make up less than $1 \%$ of all observations and are excluded from this analysis.
} 
conforming limits by county are from Fannie Mae.

\subsection{Identification and Measurement of Curtailment Payments}

We identify curtailments at the loan level by the following criteria. First, in our base specifications the curtailment payment in a given month must be at least $\$ 100$ and the sum of all curtailments must be greater than $\$ 100$ for a loan to be identified as a mortgage that exhibits curtailment behavior. ${ }^{20}$ The purpose for setting this minimum value is that in the data set there were many observations that had very small payments that likely resulted from the borrower rounding the payment amount to the nearest dollar, or even forgetting the exact amount due; these small amounts likely do not reflect a conscious effort on the part of the borrower to make additional principal payment and increase home equity.

Secondly, we filter our curtailment calculation to ensure that the curtailment amount we observe does not have a negative offset later (implying the original observation had a recording error). Additionally, we insure that the payment we observe beyond the balance due is for a borrower who is current on mortgage payments and that it results in a corresponding reduction in total balance outstanding in the following period, ensuring that the extra payment is not part of an unobservable late penalty. All observations of a mortgage while delinquent in payments are classified as having zero curtailment. However, these observations are still included in our sample, and if the loan exhibited curtailment behavior before becoming delinquent, those extra payments would still be classified as curtailments and if the borrower later becomes current, any extra payments made after the loan is reclassified as current would be considered curtailments.

Lastly, the partial prepayment must be for less than $90 \%$ of the outstanding balance to be considered a curtailment in our sample. The rationale for this criterion is that a large partial prepayment of $90 \%$ or more of the balance outstanding is effectively a prepayment in full and therefore not representative of curtailment behavior as we have defined it. This is a reasonable restriction because the vast majority of loans in our sample are early in their amortization schedules, therefore any partial prepayment of greater than $90 \%$ is akin to full prepayment; indeed most loans where such a large partial prepayment is observed are paid in full the next month. Once these restrictions are applied, there are 20,669,757 curtailment events nationwide for single family loans identified in the database in the time period January 2001 to June 2011. BBx contains nearly 95 million single family remittance records that are located in a CS-20 city; curtailment behavior is observed in approximately $4.15 \%$ of all available monthly observations across all years covered by the database.

Although curtailment amounts have a wide range of values, ${ }^{21}$ in our main specifications we treat our dependent variable, curtailment, as a dummy variable taking the value 1 if the borrower makes a curtailment payment for a given monthly remittance report, 0 otherwise. We use a binary variable to denote curtailment, because we contrast curtailment with other payment choices the borrower may make, delinquency, remaining current, or full prepayment, all of which are binary choices.

\footnotetext{
${ }^{20}$ We also set the minimum at $\$ 10$ and $\$ 1,000$ and the results do not materially change. However, it is worth noting with that with the $\$ 10$ minimum, the percentage of loans exhibiting curtailment increases, particularly in the early years of the sample to as high as $3.5 \%$ of all observations exhibiting in some months prior to 2006 .

${ }^{21}$ Curtailment amounts are allowed to range from $\$ 10, \$ 100$ or $\$ 1,000$ (depending on the specification) to $90 \%$ of current loan balance outstanding.
} 


\subsection{Independent Variables}

Previous studies identified several borrower and loan characteristics associated with borrower curtailment choices. In this section, we propose new variables potentially related to a borrower's likelihood of curtailment. Also, we provide additional insight to previously identified curtailment factors.

\subsubsection{Borrower Leverage}

Our first key independent variable uses an estimate of current loan to value ratio at each monthly observation, $t=m$. This variable is constructed with five key data points, the LTV at origination, which includes the mortgage balance at origination, $\left(M B_{t=0}\right)$, and value of the home at time of origination $\left(V_{t=0}\right)$, mortgage balance outstanding at time of observation, $\left(M B_{t=m}\right)$, the Case-Shiller index level for a given city, $i$, at origination $\left(C S^{i}{ }_{t=0}\right)$, and the Case-Shiller index level for that city, $i$, at the time of the observation $\left(C S^{i}{ }_{t=m}\right)$. A precise monthly measure of LTV is not possible, since property appraisals are conducted infrequently, and even when they are conducted, that information is not part of our data set. ${ }^{22}$ Since LTV is not updated continuously, this measure provides a reasonable proxy for the changing home price environment the borrower encounters.

The current loan to value estimate (CLTV) is given by:

$$
\text { current_ltv } v_{i t}=\left(\frac{\left(M B_{t=0}+\Delta M B\right)}{\left(V_{t=0} \cdot\left(1+\Delta C S^{i}\right)\right)}\right)
$$

where $\Delta M B$ equals the change in mortgage balance from $t=0$ to $t=m$ and $\Delta C S^{i}$ is the proportional change in the Case-Shiller index for city $i$ from $t=0$ to $t=m$.

Examining the influence of CLTV on the propensity to make curtailment payments can offer insight to the borrowers reacting to not only the change in value of their properties over time, but the amount of equity they have in their properties. The current level of borrower equity impacts many household decisions, related to the ability to qualify for a home equity loan or refinance the existing mortgage loan.

For example, a borrower who originated a loan at the height of the housing bubble with a LTV of 1 (the home purchase is $100 \%$ financed) and has been making regular payments since origination would have no trouble obtaining a refinance loan in a growing or stable housing price environment, all else equal. However, if that borrower's property is in an area which has suffered a substantial decline in housing value, the LTV may now exceed 1. If market rates have also declined since origination to the extent that refinance would be favorable for the borrower, without positive equity, refinancing may not be available. ${ }^{23}$ This gives the borrower that has sufficient disposable income or other relatively liquid and low-yield savings an incentive to adjust LTV through curtailment, and this incentive is intensified the greater the future savings refinance offers to that individual.

\footnotetext{
${ }^{22}$ As Andersson and Mayock (2014) point out, it is important to use the most accurate measure of CLTV as possible to avoid noisy equity estimates creating biases in estimates.

${ }^{23}$ Of course, exact refinance requirements for a given loan are unobservable and may vary by lender and time. However, at the extreme, a reasonable assumption is that having a non-negative equity position would be a necessary condition for finance for most borrowers.
} 
Alternatively, a borrower with very high CLTV may be underwater on their mortgage, that is they owe more on their mortgage obligation than their home is currently worth. Such borrowers may be at higher risk of delinquency or foreclosure and may be financially constrained, making them less likely to make curtailment payments.

Using the CLTV estimate, we construct an indicator variable neg_eq that takes the value of 1 if a given observation has a CLTV $>=1$, and 0 otherwise, as well as a complementary indicator variable for positive equity, where pos_eq takes the value of 1 if a given observation has a CLTV $<1$, and 0 otherwise.

Additionally, borrower leverage at origination is measured by LTV_origination. Although the relationship at origination between choice of leverage and credit spreads is likely endogenous (Titman et al 2005), we are interested in the effects of the initial choice of leverage on future payment decisions. For instance, we would expect high initial leverage to be positively associated with default probabilities, but negatively associated with curtailment or prepayment. Post-origination changes in leverage cannot affect the rate charged on the mortgage or other mortgage features that were contracted at origination of the loan, therefore there is no simultaneous feedback loop between current leverage and mortgage characteristics determined at origination.

\subsubsection{Savings Premium}

The premium over the risk free rate proxy, 12 month LIBOR, is used to measure the relative attractiveness of curtailment as an alternate investment opportunity and is calculated by:

$$
\text { savings_premium }_{i t}=\text { currentrate }_{i t}-\text { libor } 12_{t}
$$

As the premium between a mortgage's current interest rate and the prevailing short term risk-free rate grows, an investment in reducing the relatively high interest rate mortgage debt may be an attractive alternative investment to some borrowers who view the timely repayment of their mortgage as certain. For accelerated repayment of mortgage debt, borrowers may choose between curtailments and full prepayment depending on household financial situations and preferences as well as refinance eligibility and desirability.

$$
\begin{aligned}
& \text { neg_eq_savings_premium }_{i t}=\text { savings_premium }_{i t} \cdot \text { neg_eq }_{i t} \\
& \text { pos_eq_savings_premium }_{i t}=\text { savings_premium }_{i t} \cdot \text { pos_eq }_{i t}
\end{aligned}
$$

We interact the savings premium with the positive and negative equity indicator variables (pos_eq savings premium and neg_eq savings premium) to examine the savings premium on borrowers estimated to have positive and negative equity, respectively.

For mortgagors with enough home equity to be eligible for refinance, a sizable positive premium over current LIBOR should increase the relative probability of prepayment over curtailment. However, observed refinance behavior tends to lag optimal timing for refinance by an average of a year (Stanton 1995), even in periods when excess leverage does not constrain refinance ability. We would anticipate the savings premium to be positively associated with both prepayment and curtailment. However, those borrowers with negative equity may be less able to take advantage of potential savings than those with positive equity. We would expect that savings premium effects may be smaller for borrowers who may be financially constrained and have no free cash to make a curtailment payment, even as it becomes more financially attractive. 


\subsubsection{Measurement of Credit Risk}

The borrower's credit quality at origination is largely captured by observing his FICO score. FICO scores provide a method of ranking potential borrowers by the probability of having a negative credit event in the next two years, typically on a scale from 400 to 850. (Most scores are between 550 and 800.) A negative credit event can be as small as a single missed payment, or can be a large scale event like foreclosure. Borrowers with lower scores have a greater chance of all types and magnitudes of negative credit events than borrowers with higher scores. Previous studies (e.g., LaCour-Little 1999, Pennington-Cross 2003, and Ghent and Kudlyak 2011) have shown that FICO score at origination is positively associated with prepayments and negatively associated with defaults in both the prime and subprime mortgage markets. Since the curtailment option is more closely associated with prepayment than default, we would anticipate high credit quality to be associated with a higher probability of curtailment, all else equal. Similarly we would expect the relationship between fico and prepayment to also be positive.

Additionally, another dimension of borrower's riskiness is captured by the initial interest rate premium. To construct this variable, the initial interest rate on a mortgage is compared with the market rate for a similar type of mortgage at the time of loan origination. ${ }^{24}$

$$
\text { rate_premium }_{i}=\text { initialrate }_{i}-\text { marketrate }_{t=0}
$$

The initial premium attempts to capture a element of borrower risk that is not encompassed by FICO. For example, a cash out refinance mortgage typically has a higher initial interest rate than a traditional refinance. Even if the borrower has an excellent credit score, they may still have an interest rate premium on such a loan. Additionally, the rate premium may be negative for a borrower who has a below market "teaser rate" for some initial portion of the loan's life. We would expect higher values rate premium to increase the likelihood of both default for borrowers with negative equity and increased likelihood of prepayment for borrowers with positive equity, conditional on the loan not being in a period of prepayment penalty. ${ }^{25}$

\subsubsection{Adjustable and Fixed Rate Mortgages}

We denote mortgage type with an indicator variable that equals one if a loan is an adjustable rate mortgage (ARM), and zero if it is a fixed rate mortgage (FRM). Campbell and Cocco (2003) show that using a life-cycle model with borrowing constraints and income risk that an ARM is generally an attractive choice relative to a fixed-rate mortgage, but this relative attractiveness is diminished for risk-averse households with characteristics such as large mortgages and low moving probabilities.

Since ARMs typically have lower interest rates at origination than FRMs and there is a general declining interest rate regime over our sample period, ARMs may be associated with a higher rate of curtailment if the borrowers are financially non-constrained and respond to lower than anticipated monthly payments associated with declining interest rates. Additionally, making curtailment payments on ARM loans will lead

\footnotetext{
${ }^{24}$ For example, the interest rate on a 15 year fixed rate first lien mortgage is compared with the prevailing 15 year fixed mortgage rate for the month that mortgage was originated.

${ }^{25}$ Although the presence of a positive or negative deviation from market interest rate at origination may not necessarily be a measure of credit risk, because the borrower may or may not have qualified for other mortgages products, it is informative in identifying deviations from a standard contract, a choice on the part of the borrower.
} 
to a reduction in monthly balance due at the next interest reset period, but will not change the overall length of the amortization schedule. ${ }^{26}$ This ability to lower future required monthly payments may make curtailment attractive to financially non-constrained ARM borrowers. ${ }^{27}$

\subsubsection{Term of Loan}

In addition to the differential in payment amount and interest rate for loans of different lengths, the choice of a 15 or 30 year loan reveals some information about borrowers' debt preferences. ${ }^{28}$ Borrowers who choose a 15 year loan reveal their preference for a shorter term loan, which in and of itself is a form of curtailment (Adelman, Cross, and Shrider 2010). Given this, we might expect borrowers with shorter term loans to have a higher propensity to make curtailments than those that have 30 year loans. Alternatively, the future savings in reduced interest payments may offer greater pecuniary benefits for borrowers with 30 year terms than borrowers with 15 year amortization schedules, which could lead to borrowers with 30 year loans having a higher likelihood of curtailment.

\subsubsection{Loan Size}

We classify loans by size according to whether they fit the Fannie Mae conforming loan limits. For a given loan, the original balance is compared to the historic conforming limit for a loan originated in that county for that year. ${ }^{29}$ If the original loan balance is higher than the conforming limit in its year of origination, we classify that mortgage as a jumbo loan. All else equal, we would expect large loans to have a higher probability of curtailment as has been found in previous studies. ${ }^{30}$

\subsubsection{Prepayment Penalty}

A prepayment penalty indicates that the borrower may not repay the loan in full or prepay more than a portion (usually 20\%) of the loan in a single year for some specified period of time after origination without facing a substantial financial penalty. Prepayment penalties have been shown to increase the value of delaying mortgage prepayment in the commercial mortgage sector where such penalties are common (Kelly and Slawson 2001). Prepayment penalties for single-family loans largely fell out of favor in the 1980s, but by the beginning of our sample period, such penalties began to increase in popularity again.

We construct an indicator variable for prepayment penalty that equals one if a loan has a prepayment penalty at the time of a given remittance report, and zero if there is no prepayment penalty currently present for that loan. In our sample the length of the prepayment penalty ranges from 0 months to the full term of the loan. However, $61.89 \%$ of the loans contain no prepayment penalty, $5.53 \%$ have a prepayment penalty in place for one year, $11.75 \%$ for two years, $17.38 \%$ for three years, and $2.95 \%$ for five years. ${ }^{31}$ Since borrowers

\footnotetext{
${ }^{26}$ Of course, if interest rates risen, the monthly payment will also rise, but less than it would if curtailment payments had not been made.

${ }^{27}$ Additionally, ARM borrowers with teaser rates may choose to make curtailment payments near interest rate reset dates to protect against payment shock. Although we do not explicitly test this hypothesis due to data reporting limitations for some servicers, we acknowledge this may be a motivation for borrowers with initial teaser rates.

${ }^{28}$ Although loans for terms other than 15 or 30 years exist in our dataset, we limit our analysis to these two most popular loan terms.

${ }^{29}$ https://www.fanniemae.com/content/fact_sheet/historical-loan-limits.pdf.

${ }^{30}$ Budinger and Fan (1995) and Lin and Yang (2005) both find a positive relationship between loan size and curtailment probability.

${ }^{31}$ Cross-sectionally this translates into $77.19 \%$ of remittance reports having no prepayment penalty present.
} 
with prepayment penalties are only severely penalized from repaying their loans in full, all else equal, we believe that such borrowers are more likely to engage in partial prepayment, or curtailment behavior. ${ }^{32}$ Additionally, the presence of a prepayment penalty should lower the likelihood of a full prepayment, due to the large financial penalties that would result from such a decision.

\subsubsection{Documentation Level}

Another variable of interest is the level of documentation a loan is reported to have at time of origination. We create indicator variables for low documentation loans (documentation_low) and loans with unknown levels of documentation (documentation_unknown), which we compare to the base case of a full documentation loan. We would expect low documentation loans to have lower probability of curtailment and prepayment and higher chance of default relative to loans that are fully documented. Since we do not know the documentation level of the unknown documentation category, we do make predictions of this status on payment outcomes, but simply use it as a means through which we can compare loans known to have full or low documentation.

\subsubsection{Observation Year Fixed Effects}

We use a series of indicator variables to control for the year that each remittance report is observed. As suggested by the raw data, we would expect the coefficients on these variables would be increasing over time. However, unlike the raw data, we would expect the pattern of curtailment to show a more gradual increasing trend after accounting for all of the loan level variable and fixed effects.

\subsubsection{Servicer Fixed Effects}

Mortgagors' curtailment patterns may vary significantly depending on which institution services the loan. Although borrowers may curtail at anytime, many borrowers may be uneducated about this option unless informed about it by their servicer. Differences in servicer experience and competency may lead to variation in the ease of the execution of the mortgage curtailment option by borrowers. Additionally, servicer fixed effects may capture other elements related to borrower risk that are unobservable in our dataset. For example, there may be a clientele effect among servicers or certain servicers may have a high concentration of loans containing exotic features we do not have information on in our data. We use a series of indicator variables to assign loans to one of the nineteen largest servicers ${ }^{33}$ or to an additional category that encompasses all other smaller servicers' loans. Although we only observe servicer information at time of securitization, we believe this effect captures significant heterogeneity in lending practices as well as other unobservable information about borrowers.

\subsubsection{Other Fixed Effects}

Mortgagors' curtailment patterns may also vary significantly depending on when the loan is originated, where the collateral property is located, and the seasonality of the payment activity. We use a series

\footnotetext{
${ }^{32}$ Most curtailment amount are far below the $20 \%$ repayment penalty threshold; therefore borrowers with a prepayment penalty will not penalized for engaging in curtailment behavior.

${ }^{33} \mathrm{As}$ measured by percentage of loans in the BBx population serviced by a given institution.
} 
of indicator variables to control for fixed effects related to loan vintage, property location, and month of payment observation. These variables are primarily used to provide additional controls for potentially unobserved heterogeneity of borrowers. A complete list of variables is summarized in Table 2.

Table 2: Variable Descriptions

\begin{tabular}{ll}
\hline Variable & Description \\
\hline payment status & $\begin{array}{l}\text { categorical variable indicating payment choice of borrower: } \\
\text { delinquent, current, contains curtailment, or fully prepaid } \\
\text { dollar amount of curtailment }\end{array}$ \\
curtail & Estimated current loan to value ratio for loan \\
CLTV & 1 if loan has CLTV $>=1,0$ otherwise \\
neg_eq & 1 if loan has CLTV $<1,0$ otherwise \\
pos_eq & current interest rate minus current 12 month LIBOR \\
savings premium & interaction of neg_eq and savings premium \\
neg_eq savings premium & interaction of pos_eq and savings premium \\
pos_eq savings premium & 1 if adjustable rate mortgage, 0 if fixed rate mortgage \\
arm & 1 if 30 year loan, 0 if 15 year loan \\
term_30 & borrower FICO score at origination \\
fico & initial interest rate minus comparable market rate at origination \\
rate premium & 1 if original loan balance is larger than conforming loan \\
jumbo & limits for that county at time of origination, 0 otherwise \\
& 1 if loan contains a prepayment penalty, 0 otherwise \\
prepay_penalty & 1 if loan is fully documented, 0 otherwise \\
documentation_full & 1 if low documentation loan, 0 otherwise \\
documentation_low & 1 if documentation of loan unknown, 0 otherwise \\
documentation_unknown & 1 if property located in a given CS-20 city, 0 otherwise \\
city & 1 if loan originated in a given year, 0 otherwise \\
vintage & 1 if remittance report occurs in a given year, 0 otherwise \\
activity year & 1 if remittance report occurs in a given month, 0 otherwise \\
activity month & 1 if loan is handled by a given servicer, 0 otherwise \\
servicer &
\end{tabular}

\subsection{Summary Statistics}

Summary statistics for selected variables are presented in Table 3 for monthly observations that exhibit curtailment behavior (curtail=1), those that do not (curtail=0), as well as the whole sample.

There are several notable differences between the characteristics of the observations that contain curtailment payments and those that do not. Observations that have curtailment payments are more likely to be adjustable rate mortgages. Lower interest rates, which are associated with ARMs, translate into smaller monthly payments. Financially non-constrained ARM borrowers may respond to the lower interest rate by devoting some of their interest savings to reduce their mortgage debt outstanding. Additionally the average savings premium positive equity borrowers with curtailment is higher than loans with positive equity than those without curtailment. The same is true for the savings premium for borrowers with negative equity.

Table 4 presents a correlation matrix for all of the key independent variables. These correlations show there is no concern about multicollinearity problems amongst these variables (the highest correlation is 0.6373 , 
Table 3: Summary Statistics

\begin{tabular}{lrrrrrr}
\hline & No Curtail & & Curtail & \multicolumn{3}{c}{ All } \\
Variable & Mean & Std. Dev. & \multicolumn{1}{c}{ Mean } & Std. Dev. & Mean & Std. Dev. \\
\hline neg_eq & 0.1985 & 0.3989 & 0.2397 & 0.4269 & 0.2055 & 0.4041 \\
neg_eq savings premium* & 4.0750 & 1.7766 & 4.4486 & 1.7578 & 4.1487 & 1.7791 \\
pos_eq savings premium* & 2.8690 & 2.0230 & 3.2557 & 2.1678 & 2.9315 & 2.0521 \\
LTV_origination & 72.7808 & 15.2873 & 74.0575 & 14.8740 & 72.9965 & 15.2258 \\
arm & 0.5766 & 0.4940 & 0.6581 & 0.4743 & 0.5904 & 0.4918 \\
term_30 & 0.9480 & 0.2221 & 0.9568 & 0.2034 & 0.9495 & 0.2190 \\
fico & 688.4406 & 71.2190 & 673.2841 & 77.3188 & 685.8796 & 72.5086 \\
risk premium & -0.4797 & 1.7763 & -0.4666 & 2.3045 & -0.4776 & 1.8760 \\
jumbo & 0.1810 & 0.3850 & 0.1663 & 0.3724 & 0.1785 & 0.3830 \\
prepay_penalty & 0.2252 & 0.4177 & 0.2422 & 0.4284 & 0.2281 & 0.4196 \\
documentation_low & 0.4560 & 0.4980 & 0.4604 & 0.4984 & 0.4567 & 0.4981 \\
documentation_unknown & 0.1852 & 0.3884 & 0.1570 & 0.3638 & 0.1804 & 0.3845 \\
\hline
\end{tabular}

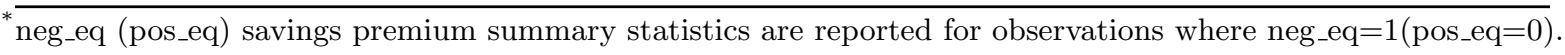

most are below 0.2). In unreported results, the correlations between all independent variables used were considered, including for all of the fixed effects variables. Most of these correlations are quite low, and none exceed 0.35 .

Table 4: Correlation Matrix

\begin{tabular}{|c|c|c|c|c|c|c|c|c|c|c|c|}
\hline Variable & neg_eq & sav prem & LTV_orig & arm & term_30 & fico & risk prem & jumbo & pp_penalty & doc_low & doc_unk \\
\hline neg_eq & 1.0000 & & & & & & & & & & \\
\hline sav prem & 0.2357 & 1.0000 & & & & & & & & & \\
\hline LTV_orig & 0.2323 & 0.1371 & 1.0000 & & & & & & & & \\
\hline arm & 0.0891 & -0.0653 & 0.2174 & 1.0000 & & & & & & & \\
\hline term_30 & 0.1016 & 0.0460 & 0.2439 & 0.2605 & 1.0000 & & & & & & \\
\hline fico & -0.0381 & -0.2838 & -0.1912 & -0.1590 & -0.0836 & 1.0000 & & & & & \\
\hline risk prem & -0.1206 & -0.6373 & -0.1841 & 0.1525 & -0.0195 & 0.3867 & 1.0000 & & & & \\
\hline jumbo & -0.0294 & -0.1292 & -0.1147 & -0.0235 & -0.0136 & 0.2487 & 0.1320 & 1.0000 & & & \\
\hline pp_penalty & 0.0172 & -0.0693 & 0.1181 & 0.1849 & 0.0809 & -0.2242 & 0.0544 & -0.1389 & 1.0000 & & \\
\hline doc_low & 0.1319 & -0.0473 & -0.1171 & -0.0608 & -0.0217 & 0.2292 & 0.1395 & 0.0381 & -0.0387 & 1.0000 & \\
\hline doc_unk & -0.1466 & 0.0723 & 0.1210 & 0.1984 & 0.0442 & -0.1853 & -0.1174 & -0.0886 & 0.0715 & -0.4302 & 1.000 \\
\hline
\end{tabular}




\section{Results}

This section presents and discusses regression results from multinominal regressions in Table 5 and the results from two-limit tobit regressions in Table 7 . For the approximately 75 million single family monthly remittance reports for properties located in CS-20 cities for which the curtailment dummy variable is populated, approximately 65 million have non-missing values for all variables of interest in our regression specification. Due to computational constraints, we take a $25 \%$ random sample by loan identifier. ${ }^{34}$

Specifically, for each variable, outcome, and curtailment level we report the estimated coefficient and associated $|z|$ statistic based on heteroskedastic robust standard errors clustered at the loan identifier level. For the single restriction of $\beta_{j}=0$ for the $j t h$ explanatory variable, one could conduct Wald inference using a z-test based on the normal cdf or using $z^{2}$ which would have a $\chi^{2}$ distribution for a two-sided test under the null hypothesis of $\beta_{j}=0$. Additionally, Table 6 presents results of a Wald test for each of the main variables of interest to assess if all coefficients associated with any given variable are significantly different from zero.

Table 7 contains tobit results for the main variables of interest. ${ }^{35}$ Specifically, the estimates and associated $t$ statistics based on heteroskedastic robust standard errors clustered at the loan level appear for the global sample, 15 and 30 year loan subsamples, and for FRM and ARM subsamples.

\subsection{Multinomial Logit Results}

We show the results from the multinomial logistic estimation in Table 5 . Moreover, Table 5 contains the results from two multinomial regressions. The first multinomial regression uses the definition of curtailment of $\$ 100$ or more (positive curtailments of less than $\$ 100$ would be treated as current, the base case). The second multinomial regression uses the definition of curtailment of $\$ 1,000$ or more (positive curtailments of less than $\$ 1,000$ would be treated as current, the base case). The reason for the different thresholds are to see if the results are sensitive to large changes in the definition of curtailment and to try to separate large from small curtailment decisions. ${ }^{36}$ Presumably, borrowers who make large curtailment payments do so more strategically than individuals who may make small curtailment decisions based on diverse behavioral criteria (dislike of debt, upward rounding of the mortgage payment to the nearest thousand, and so forth).

The regression includes several variables that should affect curtailment as well as many control variables. The main pecuniary consideration modeled involves the potential desire to curtail mortgages that charge a higher rate than the rate on savings, as specified by LIBOR. However, individuals with negative equity may wish to preserve their option to default and so may not wish to curtail even if rates are favorable. To model the effects of savings and the different incentives faced by those with positive and negative equity, we allowed for a linear trend in the predicted log-odds by including both negative equity (neg_eq) and negative equity interacted with the difference between the current mortgage rate and LIBOR (neg_eq savings premium). We also did this with positive equity which led to the variable pos_eq savings premium (but allowed the positive equity to be part of the intercept since the neg_eq and pos_eq indicator variables summed together would

\footnotetext{
${ }^{34}$ This is about 875,000 loans corresponding to approximately 18.5 million remittance reports.

${ }^{35}$ All variables contained in Table 5 are included in estimating this model, but only coefficients for key variables are reported.

${ }^{36}$ We also estimated the model with a curtailment minimum of $\$ 10$ and results are largely similar to the model with $\$ 100$ minimum curtailment value.
} 
equal a constant). Although for both curtailment multinomial regressions, the neg_equity savings premium has a larger magnitude than the pos_equity savings premium ( 0.215 versus 0.116 for the larger curtailment payment), when allowing for the large negative effect for neg_eq $(-0.852)$ the relative predicted log-odds of curtailment for those with negative equity is lower (provided the difference between the current mortgage rate and LIBOR is under 8.6\%). Therefore, borrowers with positive equity who pay a higher rate for their mortgage compared to LIBOR have increased relative odds of curtailment.

As another pecuniary variable, most prepayment penalties allow some principal reduction before imposing the penalty, and therefore curtailment offers a way to decrease mortgage balance without facing a penalty. The results show that, as anticipated, the presence of prepayment penalties increase the relative log-odds of late payments and curtailment $(0.048,0.251)$, but decrease the relative log-odds of prepayment $(-0.618)$.

In terms of important mortgage control variables, the loan-to-value at origination ( $L T V_{-}$origination) increases the relative log-odds of late payments and decreases relative odds of curtailment and prepayment for both curtailment thresholds. In contrast, ARM status raises the relative log-odds of late payments, curtailment, and prepayment relative to the base case. Borrowers with 30 year mortgages have higher relative log-odds of being late or prepayment, but lower relative odds of curtailment. Borrowers with higher FICO scores have lower relative log-odds of being late, and higher relative log-odds of curtailing or prepaying relative to the base case.

Borrowers with a higher initial spread have a lower relative log-odds of being late (although in the $\$ 100$ curtailment case this is not statistically significantly different from the base case) and higher relative logodds of curtailment and prepayment. Borrowers with jumbo loans have lower relative log-odds of being late and higher relative odds of curtailment and prepayment. Low documentation status increases the relative log-odds of late payments, but decreases relative odds of curtailment and prepayment. In contrast, unknown documentation status has higher relative odds of late payments and curtailment, but lower relative log-odds of prepayment. Note, even though curtailment represents partial prepayment the log-odds coefficient for prepayment and the log-odds coefficient for curtailment do not always share the same signs. Overall, these results are consistent with the hypotheses presented in Section 4.3.1-4.3.8.

With the exception of the risk premium variable for the late payment outcome in the $\$ 100$ threshold model, all of the variables mentioned thus far are significant at conventional levels. Also, the remaining variables are all significant across both models and all outcomes at the $0.1 \%$, with the exception of the low documentation variable for the curtailment outcome in the $\$ 1,000$ threshold model, which is significant at the $5 \%$ level. Additionally, in Table 6 provides results for a Wald test of each variable of interest across all outcomes; all covariates are significant at conventional levels. Finally, using a likelihood ratio test we reject the hypothesis that any of the outcome categories can be combined. ${ }^{37}$

\subsection{Full Sample Fixed Effects}

To control for various sources of heterogeneity, we included geography, vintage and servicer fixed effects. We control for location fixed effects by using indicators for city of property location. The variation at the servicer level is controlled with indicators for the 19 largest primary loan servicers, plus an additional category that encompasses all the smaller servicers. We also accounted for unobservable differences in lending standards

\footnotetext{
${ }^{37}$ For brevity, we omit the presentation of these results, but are happy to provide them upon request.
} 
across time by including indicator variables for year of loan origination. All loans originated in 1998, 1999, or 2000 are included in the Vintage 2000 or earlier variable and all loans originated in 2008 or later are included in the Vintage 2007 group. ${ }^{38}$

Date of loan payment observation is controlled for in two groups of variables, month fixed effects (discussed in Section 5.2.1) and year fixed effects (discussed in Section 5.2.2). The base case for each of these four groups of fixed effects is as follows: for servicer fixed effect the base case is the largest primary servicer, Countrywide Home Loans, for location effects the base case is Dallas, for vintage effects the base case is 2004, for activity year effects the base case is 2011, and for month effects the base case is December.

With regard to the servicer indicator variables, relative to Countrywide (excluded category), almost all of the servicers have significant negative relative odds of prepayment and significantly positive relative odds of curtailment. LaSalle has positive relative odds of both curtailment and prepayment. Litton and PHH have curtailment relative odds that are not statistically significant for the larger curtailment definition.

For the vintage indicator variables, all of the vintages after 2000 (with the exception of 2005) show positive relative odds of curtailment for the larger curtailment amount as compared to 2004, the year with the greatest number of new originations. For prepayment, it shows significantly positive relative odds ratios from 2000-2003 vintages, but significantly negative relative odds ratios from 2005-2007.

With regard to the city indicator variables, Boston, Los Angeles, Miami, New York, San Diego, San Francisco, and Washington D.C. all have higher relative log-odds of curtailment and prepayment for both definitions of curtailment whereas Charlotte, Phoenix, and Portland show lower relative log-odds of curtailment and higher relative log-odds of prepayment for both definitions of curtailment, relative to the base case city of Dallas. The coefficients on the larger curtailment amounts for Atlanta, Chicago, Cleveland, Denver, Las Vegas, Minneapolis, Seattle, and Tampa are not statistically significant. Again, the interest for these variables is in capturing heterogeneity rather than testing absolute and relative magnitudes.

\subsubsection{Seasonal Effects}

The seasonal effects of curtailment are shown in Figure 4. These estimates offer some interesting insights to borrower behavior and suggest some possible motivations for the timing of curtailment. ${ }^{39}$ As shown in the graph, the curtailment is most likely in December, but also shows a local maximum in April. Curtailment probabilities show a generally increasing trend from June to the end of the year. Since curtailment is a use of discretionary income and is a form of savings, it makes sense that the likelihood of curtailment is associated with times of the year where borrowers have more available discretionary income or a higher desire to save relative to desire to engage in consumption.

The higher probability of curtailment in December may be associated availability and use of end of the year bonuses, an irregular source of income that financially non-constrained borrowers may choose to devote to accelerated debt repayment. Additionally, end of year curtailment rates may be related to holiday employment. The spike in April may be associated with tax refunds, another source of irregular income

\footnotetext{
${ }^{38}$ Both of these groups include less than $1 \%$ of the total sample each, and results do not substantially change if pre-2000 or post-2007 observations are instead excluded. A small portion of the database containing loans originated before 1998 are completely excluded from the sample.

${ }^{39}$ Budinger and Fan (1995) present similar results for the seasonality of curtailment in more general terms.
} 
that borrowers may devote to mortgage curtailment. Although there is significant seasonal variation in the timing of curtailment choices, partial prepayments are observed throughout the year.

\subsubsection{Observation Year Effects}

The yearly indicator variables capture the effects of time after controlling for many individual level characteristics, geography, loan vintage, servicers, and seasonality of payments. The yearly indicator variables show a pattern of statistically significant, negative relative log-odds of curtailment that become more positive over time for both definitions of curtailment. For example, for the $\$ 1,000$ curtailment amounts the estimated coefficient for 2002 and before is -21.59 and this rises to -0.078 in 2010 . The patterns of relative log-odds for late payments and prepayment do not show such a consistent pattern.

Compared to the dramatic jump in curtailment presented in the raw curtailment data in Figure 1, the graph of the parameter estimates for observation year effects also included in Figure 1 presents a secular rise in the popularity of curtailment over the sample period. After controlling for borrower and loan variables as well as city, vintage, and seasonal fixed effects, there is no longer a sharp jump curtailment rates in 2006. The probability of curtailment shows a consistent pattern of growth of curtailment behavior beginning in 2002. 
Table 5: Late, Curtailment, and Prepayment Multinomial Logit Estimates

\begin{tabular}{|c|c|c|c|c|c|c|}
\hline \multirow[b]{2}{*}{ Variables } & \multicolumn{3}{|c|}{$\$ 100$ Minimum } & \multicolumn{3}{|c|}{$\$ 1,000$ Minimum } \\
\hline & Late & Curtail & Prepay & Late & Curtail & Prepay \\
\hline \multirow[t]{2}{*}{ neg_eq } & 0.3191 & -0.4628 & -1.0500 & 0.3326 & -0.8518 & -1.0342 \\
\hline & 25.7979 & 20.7940 & 45.8078 & 26.8959 & 17.7728 & 45.1896 \\
\hline \multirow[t]{2}{*}{ neg_eq savings premium } & 0.1616 & 0.0561 & 0.2142 & 0.1545 & 0.2151 & 0.2054 \\
\hline & 56.6626 & 10.5121 & 40.3583 & 54.2679 & 18.7095 & 38.7957 \\
\hline \multirow[t]{2}{*}{ pos_eq savings premium } & 0.1482 & 0.0092 & 0.2920 & 0.1420 & 0.1160 & 0.2837 \\
\hline & 66.2065 & 2.5457 & 116.2488 & 63.6208 & 16.3028 & 113.6475 \\
\hline \multirow[t]{2}{*}{ LTV_origination } & 0.0161 & -0.0032 & -0.0013 & 0.0162 & -0.0066 & -0.0011 \\
\hline & 70.7840 & 8.5220 & 9.0222 & 71.5308 & 9.5794 & 7.4893 \\
\hline \multirow[t]{2}{*}{ arm } & 0.3371 & 0.1462 & 0.4314 & 0.3313 & 0.5083 & 0.4241 \\
\hline & 53.8720 & 11.5977 & 82.9419 & 52.9618 & 20.9231 & 82.2001 \\
\hline \multirow[t]{2}{*}{ term_30 } & 0.1316 & -0.2210 & 0.0482 & 0.1401 & -0.6307 & 0.0572 \\
\hline & 7.0075 & 9.0427 & 4.5294 & 7.4574 & 14.9945 & 5.4384 \\
\hline \multirow[t]{2}{*}{ fico } & -0.0084 & 0.0041 & 0.0004 & -0.0085 & 0.0066 & 0.0003 \\
\hline & 197.3644 & 45.8155 & 11.5260 & 200.2674 & 37.0783 & 8.0266 \\
\hline \multirow[t]{2}{*}{ risk premium } & -0.0019 & 0.2544 & 0.0873 & -0.0182 & 0.2598 & 0.0683 \\
\hline & 1.1037 & 92.9931 & 51.6478 & 10.8541 & 51.9495 & 41.1729 \\
\hline \multirow[t]{2}{*}{ jumbo } & -0.2965 & 0.2594 & 0.0451 & -0.2972 & 1.0552 & 0.0469 \\
\hline & 36.5108 & 21.1403 & 8.4374 & 36.7160 & 51.8114 & 8.9040 \\
\hline \multirow[t]{2}{*}{ prepay_penalty } & 0.0547 & 0.0974 & -0.6072 & 0.0475 & 0.2513 & -0.6181 \\
\hline & 10.2906 & 9.6178 & 124.9288 & 8.9510 & 12.6060 & 127.6516 \\
\hline \multirow[t]{2}{*}{ documentation_low } & 0.1444 & -0.0805 & -0.1885 & 0.1479 & -0.0444 & -0.1839 \\
\hline & 24.9183 & 7.2871 & 36.6477 & 25.5470 & 2.1628 & 36.2699 \\
\hline \multirow[t]{2}{*}{ documentation_unknown } & -0.4143 & -0.2432 & 1.2965 & -0.4058 & -0.2196 & 1.3090 \\
\hline & 49.1349 & 14.1921 & 215.2107 & 47.9764 & 6.2290 & 219.0656 \\
\hline \multirow[t]{2}{*}{ Atlanta } & 0.3071 & -0.1842 & 0.3178 & 0.3125 & -0.0816 & 0.3241 \\
\hline & 18.4431 & 4.8650 & 21.6995 & 18.7294 & 0.9437 & 22.2411 \\
\hline \multirow[t]{2}{*}{ Boston } & 0.4481 & 0.1004 & 0.8083 & 0.4487 & 0.4103 & 0.8075 \\
\hline & 24.2692 & 2.6543 & 55.8253 & 24.2993 & 5.2646 & 56.2671 \\
\hline \multirow[t]{2}{*}{ Charlotte } & 0.1585 & -0.3433 & 0.3213 & 0.1638 & -0.5496 & 0.3280 \\
\hline & 6.0865 & 5.7891 & 14.9027 & 6.2627 & 4.0279 & 15.2479 \\
\hline \multirow[t]{2}{*}{ Chicago } & 0.2346 & 0.0142 & 0.6944 & 0.2342 & 0.0915 & 0.6899 \\
\hline & 15.3905 & 0.4064 & 54.1105 & 15.3368 & 1.1862 & 54.0367 \\
\hline \multirow[t]{2}{*}{ Cleveland } & 0.1877 & 0.1866 & 0.1843 & 0.1834 & 0.1266 & 0.1778 \\
\hline & 8.4313 & 3.7238 & 8.6041 & 8.2331 & 1.0004 & 8.3624 \\
\hline \multirow[t]{2}{*}{ Denver } & 0.2199 & -0.1150 & 0.4407 & 0.2278 & -0.1605 & 0.4493 \\
\hline & 11.2772 & 2.8811 & 27.1379 & 11.6674 & 1.7188 & 27.8896 \\
\hline \multirow[t]{2}{*}{ Detroit } & 0.2732 & 0.1253 & 0.3366 & 0.2700 & 0.0320 & 0.3318 \\
\hline & 16.7323 & 3.2745 & 22.0202 & 16.5159 & 0.3683 & 21.8334 \\
\hline \multirow[t]{2}{*}{ Las Vegas } & 0.1423 & -0.0945 & 0.7173 & 0.1491 & -0.0499 & 0.7230 \\
\hline & 7.8513 & 2.2642 & 44.8622 & 8.2200 & 0.5534 & 45.4986 \\
\hline \multirow[t]{2}{*}{ Los Angeles } & 0.1691 & 0.1038 & 0.9511 & 0.1723 & 0.4707 & 0.9528 \\
\hline & 12.1179 & 3.5510 & 80.2362 & 12.3298 & 7.3476 & 80.8542 \\
\hline
\end{tabular}




\begin{tabular}{|c|c|c|c|c|c|c|}
\hline Miami & $\begin{array}{r}0.2950 \\
15.2746\end{array}$ & $\begin{array}{l}0.0784 \\
1.8397\end{array}$ & $\begin{array}{r}0.6830 \\
38.9895\end{array}$ & $\begin{array}{r}0.2947 \\
15.2460\end{array}$ & $\begin{array}{l}0.2796 \\
3.0168\end{array}$ & $\begin{array}{r}0.6797 \\
38.9775\end{array}$ \\
\hline Minneapolis & $\begin{array}{r}0.2902 \\
16.1048\end{array}$ & $\begin{array}{r}-0.0502 \\
1.2961\end{array}$ & $\begin{array}{r}0.6350 \\
41.2411\end{array}$ & $\begin{array}{r}0.2928 \\
16.2394\end{array}$ & $\begin{array}{r}-0.0962 \\
1.1132\end{array}$ & $\begin{array}{r}0.6362 \\
41.6438\end{array}$ \\
\hline New York & $\begin{array}{r}0.3479 \\
25.5191\end{array}$ & $\begin{array}{l}0.2000 \\
6.8794\end{array}$ & $\begin{array}{r}0.6540 \\
56.1105\end{array}$ & $\begin{array}{r}0.3459 \\
25.3270\end{array}$ & $\begin{array}{r}0.7072 \\
11.1126\end{array}$ & $\begin{array}{r}0.6491 \\
55.9991\end{array}$ \\
\hline Phoenix & $\begin{array}{l}0.1039 \\
6.4682\end{array}$ & $\begin{array}{r}-0.1381 \\
3.7636\end{array}$ & $\begin{array}{r}0.7988 \\
58.3829\end{array}$ & $\begin{array}{l}0.1093 \\
6.7927\end{array}$ & $\begin{array}{r}-0.2080 \\
2.5079\end{array}$ & $\begin{array}{r}0.8030 \\
58.9524\end{array}$ \\
\hline Portland & $\begin{array}{r}-0.0254 \\
1.1747\end{array}$ & $\begin{array}{r}-0.1151 \\
2.6342\end{array}$ & $\begin{array}{r}0.7346 \\
45.6509\end{array}$ & $\begin{array}{r}-0.0180 \\
0.8318\end{array}$ & $\begin{array}{r}-0.2114 \\
2.1645\end{array}$ & $\begin{array}{r}0.7416 \\
46.3622\end{array}$ \\
\hline San Diego & $\begin{array}{l}0.1150 \\
6.4490\end{array}$ & $\begin{array}{l}0.0946 \\
2.7288\end{array}$ & $\begin{array}{r}0.8214 \\
57.6989\end{array}$ & $\begin{array}{l}0.1178 \\
6.6111\end{array}$ & $\begin{array}{l}0.4428 \\
6.1185\end{array}$ & $\begin{array}{r}0.8230 \\
58.2902\end{array}$ \\
\hline San Francisco & $\begin{array}{l}0.0958 \\
5.8146\end{array}$ & $\begin{array}{l}0.0836 \\
2.6484\end{array}$ & $\begin{array}{r}0.9281 \\
71.9246\end{array}$ & $\begin{array}{l}0.0981 \\
5.9562\end{array}$ & $\begin{array}{l}0.4498 \\
6.7351\end{array}$ & $\begin{array}{r}0.9298 \\
72.6523\end{array}$ \\
\hline Seattle & $\begin{array}{r}-0.0589 \\
3.2336\end{array}$ & $\begin{array}{r}-0.0249 \\
0.6881\end{array}$ & $\begin{array}{r}0.8118 \\
57.3464\end{array}$ & $\begin{array}{r}-0.0540 \\
2.9614\end{array}$ & $\begin{array}{l}0.1169 \\
1.5039\end{array}$ & $\begin{array}{r}0.8161 \\
58.0610\end{array}$ \\
\hline Tampa & $\begin{array}{l}0.1499 \\
8.4529\end{array}$ & $\begin{array}{l}0.0147 \\
0.3697\end{array}$ & $\begin{array}{r}0.6211 \\
39.6290\end{array}$ & $\begin{array}{l}0.1503 \\
8.4587\end{array}$ & $\begin{array}{l}0.0874 \\
0.9561\end{array}$ & $\begin{array}{r}0.6196 \\
39.7328\end{array}$ \\
\hline Washington D.C. & $\begin{array}{l}0.1272 \\
7.9787\end{array}$ & $\begin{array}{l}0.1292 \\
3.9545\end{array}$ & $\begin{array}{r}0.9093 \\
70.1652\end{array}$ & $\begin{array}{l}0.1261 \\
7.9063\end{array}$ & $\begin{array}{l}0.4662 \\
6.7320\end{array}$ & $\begin{array}{r}0.9055 \\
70.3288\end{array}$ \\
\hline Bank of America & $\begin{array}{r}-2.0742 \\
207.3206\end{array}$ & $\begin{array}{r}1.5746 \\
50.5679\end{array}$ & $\begin{array}{r}-1.2582 \\
159.8948\end{array}$ & $\begin{array}{r}-2.1135 \\
211.0112\end{array}$ & $\begin{array}{r}1.0889 \\
19.2202\end{array}$ & $\begin{array}{r}-1.3035 \\
165.6796\end{array}$ \\
\hline Residential Funding Corp. & $\begin{array}{r}-1.8634 \\
181.9885\end{array}$ & $\begin{array}{r}1.5581 \\
46.5901\end{array}$ & $\begin{array}{r}-1.5595 \\
193.5711\end{array}$ & $\begin{array}{r}-1.9011 \\
185.4186\end{array}$ & $\begin{array}{r}0.9664 \\
14.9690\end{array}$ & $\begin{array}{r}-1.6062 \\
199.3818\end{array}$ \\
\hline Wells Fargo & $\begin{array}{r}-1.9143 \\
188.8196\end{array}$ & $\begin{array}{r}1.7426 \\
60.3717\end{array}$ & $\begin{array}{r}-1.6696 \\
192.8570\end{array}$ & $\begin{array}{r}-1.9680 \\
194.1806\end{array}$ & $\begin{array}{r}1.3353 \\
26.0610\end{array}$ & $\begin{array}{c}-1.7344 \\
201.7064\end{array}$ \\
\hline Aurora Loan Services & $\begin{array}{r}-1.9728 \\
78.3386\end{array}$ & $\begin{array}{r}2.0909 \\
59.1100\end{array}$ & $\begin{array}{r}-1.2952 \\
105.5007\end{array}$ & $\begin{array}{r}-2.0869 \\
83.1467\end{array}$ & $\begin{array}{r}1.3398 \\
21.3220\end{array}$ & $\begin{array}{r}-1.4220 \\
124.7107\end{array}$ \\
\hline Washington Mutual & $\begin{array}{r}-1.7211 \\
138.4318\end{array}$ & $\begin{array}{r}2.0852 \\
69.1103\end{array}$ & $\begin{array}{r}-1.5282 \\
131.1909\end{array}$ & $\begin{array}{r}-1.8075 \\
145.9099\end{array}$ & $\begin{array}{r}1.5484 \\
28.9652\end{array}$ & $\begin{array}{r}-1.6388 \\
142.7432\end{array}$ \\
\hline IndyMac & $\begin{array}{r}-1.4101 \\
108.7012\end{array}$ & $\begin{array}{r}1.8236 \\
50.0518\end{array}$ & $\begin{array}{r}-2.3410 \\
180.0649\end{array}$ & $\begin{array}{r}-1.4630 \\
112.9708\end{array}$ & $\begin{array}{r}1.4885 \\
22.9921\end{array}$ & $\begin{array}{r}-2.3984 \\
185.7240\end{array}$ \\
\hline Chase Manhattan Bank & $\begin{array}{r}-1.9128 \\
151.1835\end{array}$ & $\begin{array}{r}1.5751 \\
40.5486\end{array}$ & $\begin{array}{r}-1.7741 \\
129.1677\end{array}$ & $\begin{array}{r}-1.9521 \\
154.1895\end{array}$ & $\begin{array}{r}1.0331 \\
14.3430\end{array}$ & $\begin{array}{r}-1.8174 \\
132.6852\end{array}$ \\
\hline EMC Mortgage Corp & $\begin{array}{r}-1.6635 \\
108.2580\end{array}$ & $\begin{array}{r}1.7062 \\
51.9095\end{array}$ & $\begin{array}{r}-1.5048 \\
121.5813\end{array}$ & $\begin{array}{r}-1.7289 \\
112.9139\end{array}$ & $\begin{array}{r}0.9786 \\
15.7568\end{array}$ & $\begin{array}{r}-1.5839 \\
128.7640\end{array}$ \\
\hline Ocwen & $\begin{array}{r}-1.6219 \\
122.3443\end{array}$ & $\begin{array}{r}1.3165 \\
29.9779\end{array}$ & $\begin{array}{r}-1.7642 \\
116.6599\end{array}$ & $\begin{array}{r}-1.6549 \\
124.7039\end{array}$ & $\begin{array}{l}0.5797 \\
6.4047\end{array}$ & $\begin{array}{r}-1.8041 \\
119.5170\end{array}$ \\
\hline American Mortgage Corp & $\begin{array}{r}-1.9954 \\
146.3125\end{array}$ & $\begin{array}{r}1.5092 \\
42.2674\end{array}$ & $\begin{array}{r}-2.3210 \\
133.6175\end{array}$ & $\begin{array}{r}-2.0319 \\
148.9118\end{array}$ & $\begin{array}{r}1.2241 \\
18.5696\end{array}$ & $\begin{array}{r}-2.3595 \\
136.5088\end{array}$ \\
\hline Litton Loan Servicing & $\begin{array}{r}-2.5384 \\
118.3439\end{array}$ & $\begin{array}{r}0.9105 \\
13.9846\end{array}$ & $\begin{array}{r}-1.1777 \\
109.2189\end{array}$ & $\begin{array}{r}-2.5719 \\
119.7003\end{array}$ & $\begin{array}{r}-0.0654 \\
0.3910\end{array}$ & $\begin{array}{r}-1.2216 \\
113.1569\end{array}$ \\
\hline GMAC & $\begin{array}{r}-1.7596 \\
105.9562\end{array}$ & $\begin{array}{r}1.2031 \\
18.8999\end{array}$ & $\begin{array}{r}-1.0135 \\
91.5134\end{array}$ & $\begin{array}{r}-1.7898 \\
107.7561\end{array}$ & $\begin{array}{l}0.8007 \\
6.9458\end{array}$ & $\begin{array}{r}-1.0528 \\
95.3424\end{array}$ \\
\hline Saxon Mortgage Services & $\begin{array}{r}-1.2544 \\
61.1645\end{array}$ & $\begin{array}{r}1.1955 \\
18.3835\end{array}$ & $\begin{array}{r}-2.0163 \\
106.2681\end{array}$ & $\begin{array}{r}-1.2878 \\
62.6022\end{array}$ & $\begin{array}{l}0.6863 \\
4.8939\end{array}$ & $\begin{array}{r}-2.0616 \\
108.5880\end{array}$ \\
\hline
\end{tabular}




\begin{tabular}{|c|c|c|c|c|c|c|}
\hline Wilshire Credit Corp & $\begin{array}{r}-1.7160 \\
73.5004\end{array}$ & $\begin{array}{r}1.7624 \\
44.6773\end{array}$ & $\begin{array}{r}-1.7411 \\
96.6976\end{array}$ & $\begin{array}{r}-1.7718 \\
76.0644\end{array}$ & $\begin{array}{r}1.4863 \\
21.4918\end{array}$ & $\begin{array}{r}-1.8012 \\
101.1952\end{array}$ \\
\hline Option One & $\begin{array}{r}-1.8991 \\
111.9614\end{array}$ & $\begin{array}{r}1.4427 \\
26.9815\end{array}$ & $\begin{array}{r}-1.3961 \\
107.1624\end{array}$ & $\begin{array}{r}-1.9318 \\
113.9134\end{array}$ & $\begin{array}{l}0.9344 \\
7.7713\end{array}$ & $\begin{array}{r}-1.4370 \\
110.8160\end{array}$ \\
\hline HomeEq Servicing Corp & $\begin{array}{r}-1.2898 \\
32.3225\end{array}$ & $\begin{array}{l}1.2488 \\
8.6411\end{array}$ & $\begin{array}{r}-3.2633 \\
60.0682\end{array}$ & $\begin{array}{r}-1.3249 \\
33.0572\end{array}$ & $\begin{array}{l}0.9504 \\
2.9737\end{array}$ & $\begin{array}{r}-3.3075 \\
60.9665\end{array}$ \\
\hline PHH Mortgage & $\begin{array}{r}-1.4402 \\
72.5890\end{array}$ & $\begin{array}{r}1.0540 \\
13.9669\end{array}$ & $\begin{array}{r}-3.1435 \\
98.8024\end{array}$ & $\begin{array}{r}-1.4712 \\
74.1098\end{array}$ & $\begin{array}{r}-0.0563 \\
0.3760\end{array}$ & $\begin{array}{r}-3.1849 \\
100.3249\end{array}$ \\
\hline LaSalle Bank & $\begin{array}{r}0.5039 \\
13.4731\end{array}$ & $\begin{array}{l}1.2218 \\
9.1711\end{array}$ & $\begin{array}{r}1.3908 \\
44.0843\end{array}$ & $\begin{array}{r}0.4786 \\
12.8619\end{array}$ & $\begin{array}{l}0.7664 \\
2.2797\end{array}$ & $\begin{array}{r}1.3602 \\
43.5831\end{array}$ \\
\hline All other small servicers & $\begin{array}{r}-1.6701 \\
166.7064\end{array}$ & $\begin{array}{r}1.6412 \\
54.1508\end{array}$ & $\begin{array}{r}-1.3317 \\
159.6983\end{array}$ & $\begin{array}{r}-1.7126 \\
170.9393\end{array}$ & $\begin{array}{r}1.2566 \\
23.2745\end{array}$ & $\begin{array}{r}-1.3813 \\
166.2615\end{array}$ \\
\hline Vintage 2000 and earlier & $\begin{array}{r}1.3673 \\
31.5537\end{array}$ & $\begin{array}{r}-0.2069 \\
0.8893\end{array}$ & $\begin{array}{l}0.1235 \\
2.8861\end{array}$ & $\begin{array}{r}1.3601 \\
31.3120\end{array}$ & $\begin{array}{l}0.0381 \\
0.0695\end{array}$ & $\begin{array}{l}0.1117 \\
2.6029\end{array}$ \\
\hline Vintage 2001 & $\begin{array}{r}0.7861 \\
27.8513\end{array}$ & $\begin{array}{l}0.2583 \\
2.7477\end{array}$ & $\begin{array}{l}0.1812 \\
9.2584\end{array}$ & $\begin{array}{r}0.7746 \\
27.3673\end{array}$ & $\begin{array}{l}0.4007 \\
2.7964\end{array}$ & $\begin{array}{l}0.1711 \\
8.7599\end{array}$ \\
\hline Vintage 2002 & $\begin{array}{r}0.5447 \\
30.1337\end{array}$ & $\begin{array}{l}0.2667 \\
6.5993\end{array}$ & $\begin{array}{r}0.3103 \\
29.7669\end{array}$ & $\begin{array}{r}0.5384 \\
29.8013\end{array}$ & $\begin{array}{l}0.3776 \\
5.3789\end{array}$ & $\begin{array}{r}0.3040 \\
29.5040\end{array}$ \\
\hline Vintage 2003 & $\begin{array}{r}0.1766 \\
15.6500\end{array}$ & $\begin{array}{r}-0.0099 \\
0.5007\end{array}$ & $\begin{array}{r}0.1688 \\
28.0738\end{array}$ & $\begin{array}{r}0.1794 \\
15.9178\end{array}$ & $\begin{array}{l}0.1039 \\
2.8179\end{array}$ & $\begin{array}{r}0.1741 \\
29.3368\end{array}$ \\
\hline Vintage 2005 & $\begin{array}{r}-0.0135 \\
1.5880\end{array}$ & $\begin{array}{r}-0.0302 \\
2.2389\end{array}$ & $\begin{array}{r}-0.0432 \\
8.4910\end{array}$ & $\begin{array}{r}-0.0089 \\
1.0460\end{array}$ & $\begin{array}{r}-0.0001 \\
0.0030\end{array}$ & $\begin{array}{r}-0.0378 \\
7.5567\end{array}$ \\
\hline Vintage 2006 & $\begin{array}{l}0.0423 \\
4.6348\end{array}$ & $\begin{array}{r}-0.0576 \\
3.6685\end{array}$ & $\begin{array}{r}-0.4240 \\
59.0539\end{array}$ & $\begin{array}{l}0.0486 \\
5.3376\end{array}$ & $\begin{array}{l}0.0803 \\
2.6673\end{array}$ & $\begin{array}{r}-0.4111 \\
57.8224\end{array}$ \\
\hline Vintage 2007 & $\begin{array}{r}-0.0629 \\
5.5334\end{array}$ & $\begin{array}{l}0.1424 \\
6.7395\end{array}$ & $\begin{array}{r}-0.7417 \\
62.1395\end{array}$ & $\begin{array}{r}-0.0603 \\
5.3178\end{array}$ & $\begin{array}{r}0.4544 \\
12.2207\end{array}$ & $\begin{array}{r}-0.7325 \\
61.7341\end{array}$ \\
\hline Obs. year 2002 and earlier & $\begin{array}{r}0.5225 \\
20.6902\end{array}$ & $\begin{array}{r}-24.2016 \\
363.1883\end{array}$ & $\begin{array}{r}-0.0042 \\
0.1453\end{array}$ & $\begin{array}{r}0.5705 \\
22.4972\end{array}$ & $\begin{array}{r}-21.5965 \\
194.3614\end{array}$ & $\begin{array}{l}0.0603 \\
2.0652\end{array}$ \\
\hline Obs. year 2003 & $\begin{array}{r}0.1915 \\
10.2877\end{array}$ & $\begin{array}{r}-6.7637 \\
24.5896\end{array}$ & $\begin{array}{r}-0.1423 \\
7.2297\end{array}$ & $\begin{array}{r}0.2407 \\
12.9133\end{array}$ & $\begin{array}{r}-21.5725 \\
412.8135\end{array}$ & $\begin{array}{r}-0.0756 \\
3.8510\end{array}$ \\
\hline Obs. year 2004 & $\begin{array}{r}-0.0252 \\
1.6741\end{array}$ & $\begin{array}{r}-3.2499 \\
116.0028\end{array}$ & $\begin{array}{r}-0.0164 \\
1.0041\end{array}$ & $\begin{array}{l}0.0214 \\
1.4225\end{array}$ & $\begin{array}{r}-3.7948 \\
52.5498\end{array}$ & $\begin{array}{l}0.0453 \\
2.7872\end{array}$ \\
\hline Obs. year 2005 & $\begin{array}{r}0.1653 \\
11.5691\end{array}$ & $\begin{array}{r}-1.9581 \\
97.3070\end{array}$ & $\begin{array}{r}0.9513 \\
59.2511\end{array}$ & $\begin{array}{r}0.2024 \\
14.1957\end{array}$ & $\begin{array}{r}-1.9430 \\
44.3211\end{array}$ & $\begin{array}{r}0.9964 \\
62.3696\end{array}$ \\
\hline Obs. year 2006 & $\begin{array}{r}0.3691 \\
26.3931\end{array}$ & $\begin{array}{r}-0.5963 \\
33.9424\end{array}$ & $\begin{array}{r}1.6933 \\
105.0308\end{array}$ & $\begin{array}{r}0.3783 \\
27.1346\end{array}$ & $\begin{array}{r}-0.2483 \\
6.8745\end{array}$ & $\begin{array}{r}1.7035 \\
106.1784\end{array}$ \\
\hline Obs. year 2007 & $\begin{array}{r}0.6073 \\
46.9913\end{array}$ & $\begin{array}{r}-0.5418 \\
34.3368\end{array}$ & $\begin{array}{r}1.8962 \\
122.1541\end{array}$ & $\begin{array}{r}0.6161 \\
47.8159\end{array}$ & $\begin{array}{r}-0.1413 \\
4.3636\end{array}$ & $\begin{array}{r}1.9043 \\
123.1789\end{array}$ \\
\hline Obs. year 2008 & $\begin{array}{r}0.7838 \\
70.9791\end{array}$ & $\begin{array}{r}-0.3049 \\
-26.9276\end{array}$ & $\begin{array}{r}1.0724 \\
72.5120\end{array}$ & $\begin{array}{r}0.7909 \\
71.7917\end{array}$ & $\begin{array}{r}-0.1306 \\
5.5486\end{array}$ & $\begin{array}{r}1.0761 \\
72.9764\end{array}$ \\
\hline Obs. year 2009 & $\begin{array}{r}0.3281 \\
33.7665\end{array}$ & $\begin{array}{r}-0.0991 \\
11.1819\end{array}$ & $\begin{array}{r}0.5573 \\
38.6425\end{array}$ & $\begin{array}{r}0.3290 \\
33.8845\end{array}$ & $\begin{array}{r}-0.1387 \\
7.4225\end{array}$ & $\begin{array}{r}0.5565 \\
38.6668\end{array}$ \\
\hline Obs. year 2010 & $\begin{array}{r}-0.0041 \\
0.4773\end{array}$ & $\begin{array}{r}-0.0270 \\
4.2503\end{array}$ & $\begin{array}{l}0.0018 \\
0.1179\end{array}$ & $\begin{array}{r}-0.0055 \\
0.6353\end{array}$ & $\begin{array}{r}-0.0782 \\
5.7362\end{array}$ & $\begin{array}{r}-0.0001 \\
0.0090\end{array}$ \\
\hline Obs. month January & $\begin{array}{r}-0.0413 \\
12.6119\end{array}$ & $\begin{array}{r}-0.1199 \\
31.7905\end{array}$ & $\begin{array}{r}-0.1524 \\
18.0993\end{array}$ & $\begin{array}{r}-0.0387 \\
11.8154\end{array}$ & $\begin{array}{r}-0.0663 \\
7.3490\end{array}$ & $\begin{array}{r}-0.1478 \\
17.5687\end{array}$ \\
\hline
\end{tabular}




\begin{tabular}{|c|c|c|c|c|c|c|}
\hline Obs. month February & $\begin{array}{r}-0.1897 \\
51.3851\end{array}$ & $\begin{array}{r}-0.1484 \\
39.3932\end{array}$ & $\begin{array}{r}-0.1990 \\
23.6279\end{array}$ & $\begin{array}{r}-0.1850 \\
50.1492\end{array}$ & $\begin{array}{r}-0.1158 \\
12.9049\end{array}$ & $\begin{array}{r}-0.1931 \\
22.9414\end{array}$ \\
\hline Obs. month March & $\begin{array}{r}-0.1753 \\
45.5449\end{array}$ & $\begin{array}{r}-0.1206 \\
32.7297\end{array}$ & $\begin{array}{r}-0.2213 \\
26.0617\end{array}$ & $\begin{array}{r}-0.1716 \\
44.6026\end{array}$ & $\begin{array}{r}-0.1226 \\
13.5765\end{array}$ & $\begin{array}{r}-0.2163 \\
25.4835\end{array}$ \\
\hline Obs. month April & $\begin{array}{r}-0.3047 \\
75.4927\end{array}$ & $\begin{array}{r}-0.0593 \\
15.8292\end{array}$ & $\begin{array}{r}-0.0245 \\
3.0003\end{array}$ & $\begin{array}{r}-0.3036 \\
75.2495\end{array}$ & $\begin{array}{r}-0.0417 \\
4.5979\end{array}$ & $\begin{array}{r}-0.0225 \\
2.7577\end{array}$ \\
\hline Obs. month May & $\begin{array}{r}-0.2604 \\
65.0295\end{array}$ & $\begin{array}{r}-0.1010 \\
26.5057\end{array}$ & $\begin{array}{r}-0.0410 \\
4.9955\end{array}$ & $\begin{array}{r}-0.2581 \\
64.4759\end{array}$ & $\begin{array}{r}-0.0813 \\
8.8451\end{array}$ & $\begin{array}{r}-0.0376 \\
4.5831\end{array}$ \\
\hline Obs. month June & $\begin{array}{r}-0.1972 \\
49.1080\end{array}$ & $\begin{array}{r}-0.1347 \\
33.6425\end{array}$ & $\begin{array}{l}0.0541 \\
6.6740\end{array}$ & $\begin{array}{r}-0.1936 \\
48.2183\end{array}$ & $\begin{array}{r}-0.0878 \\
9.4781\end{array}$ & $\begin{array}{l}0.0580 \\
7.1569\end{array}$ \\
\hline Obs. month July & $\begin{array}{r}-0.1335 \\
33.5719\end{array}$ & $\begin{array}{r}-0.1293 \\
32.8557\end{array}$ & $\begin{array}{r}0.1501 \\
18.7206\end{array}$ & $\begin{array}{r}-0.1297 \\
32.6253\end{array}$ & $\begin{array}{r}-0.0826 \\
9.0280\end{array}$ & $\begin{array}{r}0.1540 \\
19.2001\end{array}$ \\
\hline Obs. month August & $\begin{array}{r}-0.1218 \\
31.4563\end{array}$ & $\begin{array}{r}-0.1057 \\
28.5990\end{array}$ & $\begin{array}{l}0.0381 \\
4.6616\end{array}$ & $\begin{array}{r}-0.1185 \\
30.6193\end{array}$ & $\begin{array}{r}-0.0486 \\
5.4644\end{array}$ & $\begin{array}{l}0.0416 \\
5.0885\end{array}$ \\
\hline Obs. month September & $\begin{array}{r}-0.0995 \\
26.7530\end{array}$ & $\begin{array}{r}-0.0549 \\
15.8408\end{array}$ & $\begin{array}{l}0.0408 \\
4.9943\end{array}$ & $\begin{array}{r}-0.0988 \\
26.5815\end{array}$ & $\begin{array}{r}-0.0113 \\
1.2959\end{array}$ & $\begin{array}{l}0.0415 \\
5.0861\end{array}$ \\
\hline Obs. month October & $\begin{array}{r}-0.0021 \\
0.6078\end{array}$ & $\begin{array}{r}-0.0572 \\
16.6548\end{array}$ & $\begin{array}{r}-0.0306 \\
3.6573\end{array}$ & $\begin{array}{r}-0.0022 \\
0.6279\end{array}$ & $\begin{array}{r}-0.0278 \\
3.2272\end{array}$ & $\begin{array}{r}-0.0311 \\
3.7117\end{array}$ \\
\hline Obs. month November & $\begin{array}{r}-0.0563 \\
19.1040\end{array}$ & $\begin{array}{r}-0.0198 \\
6.8664\end{array}$ & $\begin{array}{l}0.0342 \\
4.1929\end{array}$ & $\begin{array}{r}-0.0557 \\
18.9236\end{array}$ & $\begin{array}{r}-0.0017 \\
0.2287\end{array}$ & $\begin{array}{l}0.0348 \\
4.2676\end{array}$ \\
\hline constant & $\begin{array}{r}2.0710 \\
47.6154\end{array}$ & $\begin{array}{r}-6.2123 \\
71.4391\end{array}$ & $\begin{array}{r}-5.4977 \\
147.6197\end{array}$ & $\begin{array}{r}2.1077 \\
48.4804\end{array}$ & $\begin{array}{r}-10.1327 \\
58.7720\end{array}$ & $\begin{array}{r}-5.4522 \\
147.2812\end{array}$ \\
\hline $\mathrm{N}$ observations & $18,476,303$ & & & $18,476,303$ & & \\
\hline $\mathrm{N}$ curtailment & $1,323,825$ & & & 257,298 & & \\
\hline $\mathrm{N}$ loans & 815,827 & & & 815,827 & & \\
\hline Log psuedolikelihood & $-9,796,207$ & & & $-7,080,729$ & & \\
\hline Pseudo- $\mathrm{R}^{2}$ & 0.1511 & & & 0.1651 & & \\
\hline
\end{tabular}

This table presents the multinomial logistic results for the minimum curtailment amounts of $\$ 100$ and $\$ 1,000$ with the competing choices of delinquency, current payment, curtailment, or full prepayment. The base case for both regressions is current payment status. Coefficients reported with $|z|$ below where the z statistics are based on heteroskedastic robust standard errors clustered at the loan identifier level. 
Table 6: Joint Wald Test for Multinomial models

\begin{tabular}{lcc}
\hline Variable & $\$ 100$ Threshold Model & \multicolumn{1}{l}{$\$ 1,000$ Threshold Model } \\
& $\chi^{2}(3)$ & \multicolumn{1}{c}{$\chi^{2}(3)$} \\
\hline neg_eq & $3,494.08$ & $3,398.21$ \\
neg_eq savings premium & $4,545.42$ & $4,463.08$ \\
pos_eq savings premium & $16,293.21$ & $15,598.14$ \\
LTV_origination & $5,352.24$ & $5,396.01$ \\
arm & $8,764.08$ & $8,851.54$ \\
term_30 & 152.76 & 305.63 \\
fico & $43,072.00$ & $42,574.21$ \\
risk premium & $10,119.38$ & $4,384.09$ \\
jumbo & $1,935.57$ & $4,126.39$ \\
prepay_penalty & $16,655.27$ & $17,091.48$ \\
documentation_low & $2,258.59$ & $2,240.41$ \\
documentation_unknown & $53,983.66$ & $53,950.18$ \\
\hline
\end{tabular}

This test included vintage, observation year, observation month, servicer, and city fixed effects. Although not reported in this table, the Wald statistics for each of these variables is significant at the $0.1 \%$ level (critical value 16.27). The smallest $\chi^{2}$ statistic observed is 28.73 , the value for the October variable in the $\$ 1,000$ threshold model.

Figure 4: Parameter Estimates for Seasonal Effects

Base case is December

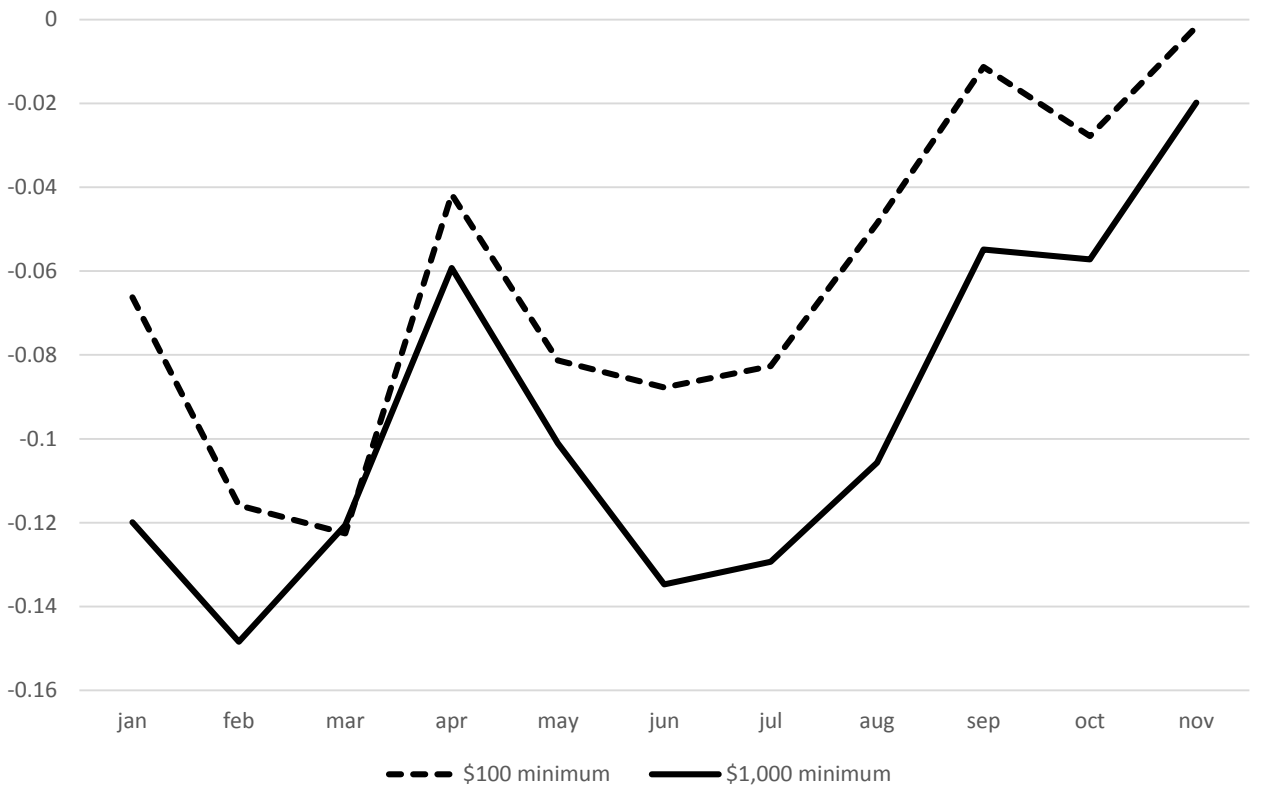




\subsection{Curtailment Amount}

We use the two-limit tobit specification described in Equation 3 to estimate the effects of borrower characteristics on the amount a borrower chooses to curtail. The results from the full sample as well as splits on loan type and loan term are presented in Table $7 .^{40}$ In each of the tobit estimations we set the minimum curtailment amount to be $\$ 1,000$. The signs of each of the variables agrees with the multinomial estimates; the amount of curtailment is positively associated with savings premiums, FICO scores, adjustable rate loans, the rate premium, prepayment penalty, and jumbo loans and is negatively associated with negative equity, original leverage, and low or unknown loan documentation levels. When $\$ 100$ is instead used as the minimum value for curtailment, the estimates remain largely similar with the exception of the two savings premium variables, which become insignificant. ${ }^{41}$ This supports the notion that large curtailers have more of a savings motivation relative to borrowers who make small curtailment payments.

Within the tobit setting we examine the effects of different term (15 year versus 30 year) and type (FRM versus ARM) on the amount a borrower chooses to curtail. For the loan term comparison we create interaction variables between indicator variables for 15 and 30 year loans and each of the key variables and then estimate a single model containing all of the interaction terms as well as all of the fixed effects. The coefficient estimates for each of the key variables for both 15 and 30 year loans are reported in the second and third column of Table 7. We then test if the estimates of each variable is different for the two loan terms and report if the estimates are significantly different in the subsequent column. Borrowers with 15 year loans have significantly different coefficients from borrowers with 30 year loans for savings premium (among borrowers with positive equity), leverage at origination, FICO scores, initial rate premiums, and prepayment penalties.

Additionally, several variables that are predictive of 30 year loan curtailment amount are insignificant among 15 year borrowers. Although in the global model 30 year loans were associated with smaller curtailment amounts, as mentioned in Section 4.3.5, 15 year loans may tend to have more behavioral reasons for curtailment while 30 year loans may have more pecuniary motives, given the greater interest costs associated with longer term loans.

We then follow the same procedure for testing the differential effects of fixed and adjustment rate mortgage on the amount curtailed. In this specification the sample is more evenly split with $59 \%$ of the sample containing observations for adjustable rate loans. In this specification all of the coefficients for the key variables are significantly different between FRMs and ARMs, except for the negative equity indicator and the indicator for low documentation loans. Also, some of the variables that are predictive of ARM curtailment amounts are not significant for FRM loans (neg_eq savings premium, LTV_origination, prepay_penalty, and documentation_unknown). However, the remaining variables are still significantly predictive of the amount of curtailment chosen by fixed rate borrowers, suggesting that factors such as higher creditworthiness, larger loans, and positive equity positions are the primary considerations of larger curtailment amounts for FRM loans.

In general, the results from the multinomial and tobit models are consistent; the variables that are predictive of the curtailment choice are also predictive of the amount a borrower chooses to curtail.

\footnotetext{
${ }^{40}$ All geographic, vintage, observation year, observation month, and servicer fixed effects used in the multinomial model were included in estimation, but the output is omitted.

${ }^{41}$ Results from $\$ 100$ minimum curtailment value are omitted from Table 7 , but available upon request.
} 
Table 7: Tobit Global and Subsample Estimates

\begin{tabular}{|c|c|c|c|c|c|c|c|}
\hline Variables & Global & $15 \mathrm{yr}$ & $30 \mathrm{yr}$ & $\Delta$ & FRM & ARM & $\Delta$ \\
\hline neg_eq & $\begin{array}{r}-1,984.4910 \\
-18.1122\end{array}$ & $\begin{array}{r}-1,388.6090 \\
-0.7336\end{array}$ & $\begin{array}{r}-1,956.0300 \\
-17.8272\end{array}$ & & $\begin{array}{r}-1,597.3940 \\
-7.0537\end{array}$ & $\begin{array}{r}-1,982.1330 \\
-16.1800\end{array}$ & \\
\hline neg_eq savings premium & $\begin{array}{r}533.2325 \\
20.2472\end{array}$ & $\begin{array}{r}-35.8444 \\
-0.0839\end{array}$ & $\begin{array}{r}525.1784 \\
20.0762\end{array}$ & & $\begin{array}{r}103.3266 \\
1.7566\end{array}$ & $\begin{array}{r}568.1202 \\
19.7579\end{array}$ & $* * *$ \\
\hline pos_eq savings premium & $\begin{array}{r}323.6201 \\
17.9115\end{array}$ & $\begin{array}{r}47.2302 \\
0.7517\end{array}$ & $\begin{array}{r}328.7429 \\
17.7707\end{array}$ & $* * *$ & $\begin{array}{r}63.5712 \\
2.0106\end{array}$ & $\begin{array}{r}355.0056 \\
17.2053\end{array}$ & $* * *$ \\
\hline LTV_origination & $\begin{array}{l}-19.2147 \\
-11.3685\end{array}$ & $\begin{array}{l}8.0738 \\
1.7941\end{array}$ & $\begin{array}{l}-22.5075 \\
-12.7523\end{array}$ & $* * *$ & $\begin{array}{l}-1.4079 \\
-0.5904\end{array}$ & $\begin{array}{l}-30.8042 \\
-14.1948\end{array}$ & $* * *$ \\
\hline arm & $\begin{array}{r}1,247.1800 \\
21.6219\end{array}$ & $\begin{array}{r}2,059.6880 \\
2.9432\end{array}$ & $\begin{array}{r}1,293.5821 \\
22.2382\end{array}$ & & 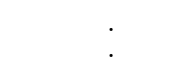 & . & \\
\hline term_30 & $\begin{array}{r}-1,674.4240 \\
-16.4637\end{array}$ & . & . & & $\begin{array}{r}-1,884.5811 \\
-17.7934\end{array}$ & $\begin{array}{r}-2,225.5248 \\
-5.3229\end{array}$ & $* *$ \\
\hline fico & $\begin{array}{l}15.7525 \\
35.5233\end{array}$ & $\begin{array}{l}16.6913 \\
26.2136\end{array}$ & $\begin{array}{l}15.6538 \\
35.1927\end{array}$ & * & $\begin{array}{l}13.3307 \\
22.6992\end{array}$ & $\begin{array}{l}17.0335 \\
34.9980\end{array}$ & $* * *$ \\
\hline rate premium & $\begin{array}{r}630.9389 \\
48.6696\end{array}$ & $\begin{array}{r}260.3274 \\
2.1148\end{array}$ & $\begin{array}{r}632.4170 \\
48.5500\end{array}$ & $* *$ & $\begin{array}{r}295.7174 \\
5.5112\end{array}$ & $\begin{array}{r}622.8852 \\
46.7163\end{array}$ & $* * *$ \\
\hline prepay_penalty & $\begin{array}{r}515.5441 \\
10.9988\end{array}$ & $\begin{array}{r}-308.1352 \\
-0.9385\end{array}$ & $\begin{array}{r}593.8134 \\
12.4095\end{array}$ & $* *$ & $\begin{array}{r}-216.2385 \\
-1.8775\end{array}$ & $\begin{array}{r}784.3930 \\
15.0902\end{array}$ & $* * *$ \\
\hline jumbo & $\begin{array}{r}2,846.7000 \\
48.8610\end{array}$ & $\begin{array}{r}3,106.5090 \\
16.0987\end{array}$ & $\begin{array}{r}2,796.6070 \\
46.9568\end{array}$ & & $\begin{array}{r}2,869.0190 \\
33.8649\end{array}$ & $\begin{array}{r}2,788.8460 \\
39.7518\end{array}$ & $* * *$ \\
\hline documentation_low & $\begin{array}{r}-135.6321 \\
-2.7549\end{array}$ & $\begin{array}{r}-449.6538 \\
-2.4024\end{array}$ & $\begin{array}{r}-90.5241 \\
-1.7799\end{array}$ & & $\begin{array}{r}-318.6525 \\
-4.1676\end{array}$ & $\begin{array}{r}-21.0109 \\
-0.3288\end{array}$ & \\
\hline documentation_unknown & $\begin{array}{r}-778.6440 \\
-9.8610\end{array}$ & $\begin{array}{r}-1,210.7930 \\
-2.9203\end{array}$ & $\begin{array}{r}-501.4495 \\
-6.2316\end{array}$ & & $\begin{array}{r}-304.1952 \\
-1.9020\end{array}$ & $\begin{array}{r}-573.9149 \\
-6.5361\end{array}$ & $* *$ \\
\hline Left-censored observations & $16,284,395$ & & & & & & \\
\hline Right-censored observations & 11,448 & & & & & & \\
\hline Pseudo- $R^{2}$ & 0.0545 & 0.0554 & & & 0.0558 & & \\
\hline
\end{tabular}

*,**,*** indicate subsamples significantly different at 5\%, 1\%, and $0.1 \%$ levels, respectively. Vintage, observation year, observation month, servicer, and city fixed effects included but not reported. Coefficients reported with t-statistics below where the $t$ statistics are based on heteroskedastic robust standard errors clustered at the loan identifier level. 


\section{Conclusions and Future Research}

Historically, curtailment has been a prominent borrower behavior in Asian markets, but largely absent from or considered to be of little significance in the US mortgage market. However, the rate of curtailment for US borrowers experienced tremendous growth in the past decade. In fact, curtailment is a fairly common behavior that we observe in $6 \%$ or more of all mortgages each month from 2006 onwards. Additionally, $30 \%$ of all mortgages in our sample as of 2011 have at least one remittance report containing a curtailment payment.

We develop a model to identify borrower and loan specific variables that are associated with a higher probability of making a curtailment payment. We show that curtailment is more likely for borrowers with higher credit scores, shorter loan terms, lower leverage at origination, and current positive equity, all characteristics associated with lower default risk. Borrowers with a prepayment penalty have an increased probability of curtailment (and lower probability of prepayment in full), illustrating that curtailment can be an attractive choice for borrowers desiring to reduce debt outstanding, but facing substantial financial penalties for full prepayment of their loan. Additionally, we provide support to the savings hypothesis of curtailment by presenting evidence that borrowers accelerate repayment of relatively expensive debt.

Most importantly, after controlling for borrower and loan-level variables, as well as fixed effects for geography, year of origination, servicers, and seasonality, we show that the propensity to curtail has increased over the sample period. Interestingly, the increase in curtailment behavior predates the deleveraging trend observed in aggregate consumer debt. We show that mortgage curtailment is both common enough and has enough economic significance to warrant additional attention, which may lead to new insights.

For example, do borrowers who curtail (low current value of default option) but subsequently default provide a control group of non-strategic defaulters (McCollum and Pace 2014)? Could curtailment act as a barometer of local housing market fundamentals? Does curtailment predict prepayment motivation (moving versus interest rate savings)? 
[1] Abrahams, B. The new view in mortgage prepayments: Insight from analysis at the loan-by-loan level. Journal of Fixed Income 7, 1 (1997), 8-21.

[2] Adelman, S. W., Cross, M. L., and Shrider, D. G. Why do homeowners make mortgage curtailment payments? Journal of Housing Research 19, 2 (2010), 195-212.

[3] Agarwal, S., Chang, Y., and Yavas, A. Adverse selection in mortgage securitization. Journal of Financial Economics 105 (2012), 640-660.

[4] Amromin, G., Huang, J., And Sialm, C. The tradeoff between mortgage prepayments and taxdeferred retirement savings. Journal of Public Economics 91 (2007), 2014-2040.

[5] Andersson, F., And Mayock, T. Loss severities on residential real estate debt during the great recession. Journal of Banking and Finance 46 (2014), 266-284.

[6] Archer, W., Ling, D., And McGill, G. The effect of income and collateral constraints on residential mortgage terminations. Regional Science and Urban Economics 26 (1996), 235-261.

[7] Bricker, J., Bucks, B. K., Kennickell, A., Mach, T. L., and Moore, K. Drowning or weathering the storm? changes in family finances from 2007 to 2009. NBER Working Paper 16985, April 2011.

[8] Brown, M., Haughwout, A., Lee, D., and van der Klaauw, W. The financial crisis at the kitchen table: Trends in household debt and credit. Federal Reserve Bank of New York Staff Reports, December 2010.

[9] Brown, S., Garino, G., Taylor, K., and Price, S. Debt and financial expectations: an individualand household-level analysis. Economic Inquiry 43 (2005), 100-120.

[10] Budinger, M., And Fan, Y. Rfc whole loan prepayment behavior. The Handbook of Mortgage Backed Securities Chapter 13 (1995), 34-51.

[11] Campbell, J. Y. Household finance. Journal of Finance 61, 4 (2006), 1553-1604.

[12] Campbell, J. Y., And Cocco, J. F. Household risk management and optimal mortgage choice. The Quarterly Journal of Economics 118, 4 (2003), 1449-1494.

[13] Chakrabarti, R., Lee, D., van der Klaauw, W., and Zafar, B. Household debt and saving during the 2007 recession. NBER Working Paper 16999, April 2011.

[14] Chinloy, P. Elective mortgage prepayment: Termination and curtailment. Journal of the American Real Estate and Urban Economics Association 21, 3 (1993), 313-332.

[15] Clapp, J., Deng, Y., And An, X. Unobserved heterogeneity in models of competing mortgage termination risk. Real Estate Economics 34 (2006), 243-274.

[16] Clapp, J., Goldberg, G., Harding, J., and LaCour-Little, M. Movers and shuckers: Interdependent prepayment decisions. Real Estate Economics 29 (2001), 411-450.

[17] Daglish, T. What motivates a subprime borrower to default. Journal of Banking and Finance 33 (2009), 681-693. 
[18] FEI, P. A note on applying option pricing theory to emerging mortgage and mortgage-backed securities markets. Applied Economic Letters 17 (2010), 881-885.

[19] Fu, Q. Retiring Early: An Empirical Analyis of the Mortgage Curtailment Decision. PhD thesis, University of Wisconsin, 1997.

[20] Ghent, A. C., And Kudlyak, M. Recourse and residential mortgage default: Evidence from us states. Review of Financial Studies 24 (2011), 3139-3186.

[21] Hayre, L., and Lauterbach, K. Partial and full prepayments and the modeling of mortgage cash flows. Journal of Fixed Income 1, 2 (1991), 37-42.

[22] Justiniano, A., Primiceri, G., and Tambalotti, A. Household leveraging and deleveraging. NBER Working Paper 18941, April 2013.

[23] Kau, J., Keenan, D., Muller, W., And Epperson, J. A generalized valuation model for fixed-rate residential mortgages. Journal of Money, Credit and Banking 24 (1992), 279-299.

[24] KaU, J., And Kennan, D. An overview of the option-theoretic pricing of mortgages. Journal of Housing Research 6 (1995), 217-244.

[25] Kau, J., Kennan, D., Muller, W., and Epperson, J. The valuation at origination of fixed-rate mortgages with default and prepayment. Real Estate Finance and Economics 11 (1995), 5-36.

[26] Kelly, A., and Slawson, V. Time-varying mortgage prepayment penalties. Journal of Real Estate Finance and Economics 23, 2 (2001), 235-254.

[27] LaCour-Little, M. Another look at the role of borrower characteristics in predicting mortgage prepayments. Journal of Housing Research 10, 1 (1999), 1052-1101.

[28] LaCour-Little, M. Mortgage termination risk: A review of the recent literature. Journal of Real Estate Literature 16 (2008), 297-326.

[29] Lea, S., Webley, P., And Levine, R. M. The economic psychology of consumer debt. Journal of Economic Psychology 14 (1993), 85-119.

[30] Lea, S., Webley, P., And Walker, C. Psychological factors in consumer debt: Money management, economic socialization, and credit use. Journal of Economic Psychology 15 (1995), 681-701.

[31] Lin, C.-C., Chu, T.-H., Prather, L. J., And Wang, P. Mortgage curtailment and default. International Real Estate Review 8, 1 (2005), 95-109.

[32] Lin, C.-C., And YAng, T. T. Curtailment as a mortgage performance indicator. Journal of Housing Economics 14 (2005), 294-314.

[33] Lunt, P., And Livingstone, S. M. Psychological, social and economic determinants of saving: Comparing recurrent and total savings. Journal of Economic Psychology 12 (1991), 621-641.

[34] McCollum, M. N., And Pace, R. K. Good borrowers gone bad: Using curtailment to examine strategic mortgage default. Working Paper, March 2015. 
[35] Pafenberg, F. Single-family mortgages originated and outstanding: 1990-2004. Office of Federal Housing Enterprise Oversight (2005), 1-16.

[36] Pennington-Cross, A. Credit history and the performance of prime and nonprime mortgages. Journal of Real Estate Finance and Economics 27, 3 (2003), 279-301.

[37] Quigley, J., And Order, R. V. Efficiency in the mortgage market: the borrower's perspective. Journal of the American Real Estate and Urban Economics Association 11 (1995), 99-117.

[38] Stanton, R. Rational prepayment and the valuation of mortgage-backed securities. Review of Financial Studies 8 (1995), 667-708.

[39] Titman, S., Tompaidis, S., and Tsyplakov, S. Determinants of credit spreads in commercial mortgages. Real Estate Economics 33 (2005), 711-738.

[40] Weller, C. E. Need or want: What explains the run-up in consumer debt? Journal of Economic Issues 2 (2007), 583-591. 